\title{
Nitrogen oxides and ozone fluxes from an oilseed-rape management cycle: the influence of cattle slurry application
}

\author{
Raffaella M. Vuolo ${ }^{1}$, Benjamin Loubet ${ }^{1}$, Nicolas Mascher ${ }^{1}$, Jean-Christophe Gueudet ${ }^{1}$, Brigitte Durand ${ }^{1}$, \\ Patricia Laville $^{1}$, Olivier Zurfluh ${ }^{1}$, Raluca Ciuraru ${ }^{1}$, Patrick Stella ${ }^{2}$, and Ivonne Trebs ${ }^{3}$ \\ ${ }^{1}$ UMR ECOSYS, INRA, AgroParisTech, Université Paris-Saclay, 78850, Thiverval-Grignon, France \\ ${ }^{2}$ UMR SADAPT, AgroParisTech, INRA, Université Paris-Saclay, 16 rue Claude Bernard, 75231 Paris, France \\ ${ }^{3}$ Luxembourg Institute of Science and Technology (LIST), Environmental Research and Innovation (ERIN), \\ 41 rue du Brill, 4422 Belvaux, Luxembourg
}

Correspondence to: Benjamin Loubet (benjamin.loubet@inra.fr)

Received: 11 May 2016 - Discussion started: 29 June 2016

Revised: 6 January 2017 - Accepted: 26 January 2017 - Published: 2 May 2017

\begin{abstract}
This study reports $\mathrm{NO}, \mathrm{NO}_{2}$ and $\mathrm{O}_{3}$ mixing ratios and flux measurements using the eddy covariance method during a 7-month period over an oilseed-rape field, spanning an organic and a mineral fertilisation event. Cumulated NO emissions during the whole period were in agreement with previous studies and showed quite low emissions of $0.26 \mathrm{~kg} \mathrm{~N} \mathrm{ha}^{-1}$ with an emission factor of $0.27 \%$, estimated as the ratio between total $\mathrm{N}$ emitted in the form of $\mathrm{NO}$ and total $\mathrm{N}$ input. The NO emissions were higher following organic fertilisation in August due to conditions favouring nitrification (soil water content around $20 \%$ and high temperatures), while mineral fertilisation in February did not result in high emissions. The ozone deposition velocity increased significantly after organic fertilisation. The analysis of the chemical and turbulent transport times showed that reactions between $\mathrm{NO}, \mathrm{NO}_{2}$ and $\mathrm{O}_{3}$ below the measurement height occurred constantly throughout the 7-month period. Following organic fertilisation, the NO ground fluxes were $30 \%$ larger than the NO fluxes at the measurement height $(3.2 \mathrm{~m})$, while the $\mathrm{NO}_{2}$ fluxes switched from deposition to emission during certain periods, being negative at the surface and positive at the measurement height. This phenomenon of "apparent $\mathrm{NO}_{2}$ emissions" appears to be significant during strong $\mathrm{NO}$ emissions and high $\mathrm{O}_{3}$ ambient mixing ratios, even on a bare soil during August.
\end{abstract}

\section{Introduction}

Agricultural soils represent an important source of atmospheric nitric oxide (NO), especially in highly fertilised regions (Oikawa et al., 2015). Global estimates of total $\mathrm{NO}_{x}$ $\left(\mathrm{NO}+\mathrm{NO}_{2}\right)$ emissions from soils range between 4 and $21 \mathrm{Tg} \mathrm{Nyr}^{-1}$, which represents between 10 and $15 \%$ of the global $\mathrm{NO}_{x}$ budget (Davidson and Kingerlee, 1997; IPCC, 2001; Yienger and Levy, 1995). $\mathrm{NO}_{x}$ inventories are subject to error in magnitude and especially in spatial distributions (Martin et al., 2003), which can be constrained by satellite observations and range around $30 \%$ at the global scale (Toenges-Schuller et al., 2006). $\mathrm{NO}_{x}$ emissions are of considerable interest also for atmospheric photochemistry, and acting as ozone $\left(\mathrm{O}_{3}\right)$ precursors, they indirectly have an impact on climate. $\mathrm{O}_{3}$ is indeed an important greenhouse gas, contributing to $25 \%$ of the anthropogenic net radiative forcing (IPCC, 2007).

$\mathrm{NO}_{x}$, and especially $\mathrm{NO}_{2}$, are toxic gases for humans, exposure to which increases risks of various respiratory diseases. The World Health Organization gives guidelines for $\mathrm{NO}_{2}$ exposure limits, both annual means $\left(40 \mu \mathrm{g} \mathrm{m}^{-3}\right)$ and $1 \mathrm{~h}$ mean $\left(200 \mu \mathrm{g} \mathrm{m}^{-3}\right)$ (Prüss-Üstün et al., 2016). For $\mathrm{O}_{3}$, only a short-term threshold is given $\left(100 \mu \mathrm{g} \mathrm{m}^{-3}\right.$ for the $8 \mathrm{~h}$ mean) because there are fewer studies on long-term exposure. These thresholds are established both in epidemiological and toxicological studies on humans and animals. Similarly, nitrogen deposition leads to serious adverse effects on the ecosystem (eutrophication, biodiversity erosion and acidification being 
the most serious ones), while $\mathrm{O}_{3}$ has a direct adverse effect on plant health through oxidation of photosynthesis pathways and direct tissue destruction above large thresholds. For nitrogen, the concept of critical load has been developed which gives the amount of nitrogen deposition above which an ecosystem is impacted. These critical loads range from $5 \mathrm{~kg} \mathrm{Nha}^{-1} \mathrm{yr}^{-1}$ for sensitive habitats to $20 \mathrm{~kg} \mathrm{Nha}^{-1} \mathrm{yr}^{-1}$ for less sensitive ones (APIS, 2016). For these reasons, national and international authorities regulate atmospheric levels of these pollutants.

$\mathrm{NO}_{x}$ emissions from soils are primarily the by-products of nitrification and denitrification processes and the chemical decomposition of $\mathrm{HNO}_{2}$ (Laville et al., 2005; Meixner, 1997; Remde et al., 1989). Many authors emphasise that for most agricultural soils, nitrification is the dominant process of NO emissions (Bollmann et al., 1999; Dunfield and Knowles, 1999; Godde and Conrad, 2000). Organic and mineral fertilisers, rich in ammonium, increase NO emissions both by stimulating NO production by nitrification and by decreasing NO consumption.

There is a significant knowledge gap in understanding $\mathrm{NO}_{x}$ exchanges between agricultural ecosystems and the atmosphere, partly due to a lack of direct measurements over long periods. NO emissions by soils can either be measured by dynamic chambers (Breuninger et al., 2012; Laville et al., 2009, 2011; Pape et al., 2009), aerodynamic gradient (Kramm et al., 1991), or eddy covariance methods (Rummel et al., 2002; Stella et al., 2013a). Each method has its drawbacks and challenges. The dynamic chamber method may change the surface exchange parameters (Pape et al., 2009), and modify the fluxes due to fast reactions between the triad $\mathrm{O}_{3}-\mathrm{NO}-\mathrm{NO}_{2}$, but thoroughly designed Teflon chambers can overcome this problem (Skiba et al., 2009). The aerodynamic gradient method (AGM) is a well-established method applicable to water-soluble compounds such as $\mathrm{NH}_{3}$ (Milford et al., 2009), but has several biases of which flux divergence due to chemical reactions is the most limiting for $\mathrm{NO}-\mathrm{NO}_{2}-$ $\mathrm{O}_{3}$ (Duyzer et al., 1995; Kramm et al., 1991; Loubet et al., 2013). Non-stationarity and integration time are also limiting (Lenschow et al., 1994; Stella et al., 2012). The eddy covariance method is adapted for measuring NO fluxes. It is however also vulnerable to flux divergence issues due to $\mathrm{NO}-\mathrm{NO}_{2}-\mathrm{O}_{3}$ chemical reactions. It is therefore essential to measure the fluxes and mixing ratios of the three compounds together.

The eddy covariance (EC) method is the state-of-the-art flux measurement method for energy and $\mathrm{CO}_{2}$ fluxes (Baldocchi, 2003), and due to the development of new analysers such as fast chemiluminescence, quantum cascade lasers, absorption spectroscopy, or proton time-of-flight mass spectrometers (Ammann et al., 2012; Brodeur et al., 2009; Ferrara et al., 2012; Li et al., 2013; Müller et al., 2010; Park et al., 2014; Peltola et al., 2014; Sintermann et al., 2011; Stella et al., 2013a; Wolfe et al., 2009) it can currently be applied to several other trace gases. The main advantage of the EC method is that it is a "direct" measurement of the flux at a given height, which depends on fewer assumptions than the AGM, namely the Reynolds averaging and ergodicity hypothesis requiring that "the averaging time must be much larger than the timescales of variation of the air velocity" (Corrsin, 1975, see also Kaimal and Finnigan, 1994). This method has been successfully applied for measuring NO fluxes in a limited number of studies (Eugster and Hesterberg, 1996; Lee et al., 2015; Marr et al., 2013; Min et al., 2014; Rummel et al., 2002; Stella et al., 2013a). The main difficulties of EC measurements are the losses that appear at high frequencies due to adsorption of the gas to the tubing system, which depends also on the size of the absorption cell (Eugster and Senn, 1995) and differential advection caused by the radial variation of the mean velocity and simultaneous radial diffusion of the sample gas (Lenschow and Raupach, 1991). Moreover, since $\mathrm{NO}_{2}$-to-NO photolytic converters typically applied in combination with chemiluminescence analysers have a conversion efficiency below $100 \%$, measuring both $\mathrm{NO}$ and $\mathrm{NO}_{2}$ with such a converter remains a challenge that requires the use of two analysers simultaneously (Lee et al., 2015).

Due to these limitations, simultaneous measurements of $\mathrm{NO}, \mathrm{NO}_{2}$ and $\mathrm{O}_{3}$ fluxes by $\mathrm{EC}$ have hence seldom been made. To our knowledge, only a few studies report such measurements and none over an arable crop. There is therefore a gap in knowledge as to whether the reactions between $\mathrm{NO}, \mathrm{NO}_{2}$ and $\mathrm{O}_{3}$ significantly influence the fluxes above crops and how nitrogen application modifies these fluxes and their interactions. Eugster and Senn (1995) report $\mathrm{NO}_{2}$ fluxes by EC and analyse the errors of the method. Most studies conducted over forests show moderate to large in-canopy reactions: Andreae et al. (2002) report comprehensive flux measurements in the Amazonian forest showing evidence of within-forest cycling of the nitrogen oxides emitted from the soil. Horii et al. (2004) report $\mathrm{NO}_{x}$ and $\mathrm{O}_{3}$ fluxes over a temperate deciduous forest showing consistent $\mathrm{NO}_{x}$ deposition. Geddes and Murphy (2014) report such measurements over two mixed hardwood forests in North America, under a very low NO concentrations regime, which show mainly $\mathrm{NO}_{x}$ deposition with evidence of chemical reactions in the canopy. Min et al. (2014) report such flux measurements over ponderosa pines which shows evidence of within-canopy chemical removal of $\mathrm{NO}_{x}$. Ammann et al. (2012) report total reactive nitrogen fluxes by EC above grassland which compared well with dynamic chamber $\mathrm{NO}$ and $\mathrm{NO}_{2}$ fluxes during periods with no $\mathrm{NH}_{3}$ emissions. Lee et al. (2015) and Marr et al. (2013) report fluxes of $\mathrm{NO}$ and $\mathrm{NO}_{2}$ over urban areas which differ in their comparison with national emissions inventories: while Lee et al. (2015) found fluxes $80 \%$ higher than national inventories, the second study found similar fluxes but with large disparities at the local scale.

In this study we are addressing the following questions: (1) is the EC method suitable for quantifying the seasonal dynamics and diurnal cycles of the $\mathrm{NO}, \mathrm{NO}_{2}$ and $\mathrm{O}_{3}$ fluxes 
above a crop rotation? (2) How are organic and mineral fertilisations affecting these fluxes and their dynamics? (3) To what extent are the chemical reactions between $\mathrm{NO}, \mathrm{NO}_{2}$ and $\mathrm{O}_{3}$ modifying the fluxes above the ground? And finally, (4) why is $\mathrm{O}_{3}$ deposition increasing following organic fertilisation? Is that a consequence of interactions with NO emissions?

To answer these questions we report measurements of $\mathrm{NO}$, $\mathrm{NO}_{2}$ and $\mathrm{O}_{3}$ fluxes by EC using a system similar to Lee et al. (2015) for 1 month following slurry spreading over a bare soil at the FR-GRI FLUXNET and ICOS site (Loubet et al., 2011). The $\mathrm{NO}$ and $\mathrm{O}_{3}$ fluxes were measured over an additional 6-month period to study the seasonality of these fluxes and to measure the fluxes following application of mineral fertiliser.

\section{Materials and methods}

\subsection{Site description and management}

The experiment took place in a 19 ha field located at Grignon $\left(48^{\circ} 51^{\prime} \mathrm{N}, 1^{\circ} 58^{\prime} \mathrm{E}\right), 40 \mathrm{~km}$ west of Paris (France) and lasted more than 7 months from 7 August 2012 to 13 March 2013. The field was surrounded by heavy traffic roads on the east, south and southwest. The field belongs to a large farm (buildings at around $450 \mathrm{~m}$ to the southwest) with around 210 dairy cows, 500 sheep, and a production of approximately 900 lambs. The terrain has a gentle slope of $\sim 1 \%$ and the mean annual temperature and precipitation were $10.9^{\circ} \mathrm{C}$ and $575 \mathrm{~mm}$ between 2005 and 2013. The main wind directions are northwest during clear days and southwest during cloudy and rainy days. The soil type is a Luvisol or loamy clay ( $25 \%$ clay, $70 \%$ silt, $5 \%$ sand in the top $15 \mathrm{~cm}$ ). The soil organic carbon content was $\sim 20 \mathrm{~g} \mathrm{C} \mathrm{kg}^{-1}, \mathrm{pH}$ (in water) $=7.6$, and bulk soil density was $1.3 \mathrm{~g} \mathrm{~m}^{-3}$, in agreement with previous measurements on the same site (Laville et al., 2009, 2011; Loubet et al., 2011). High pH values are common in soils over calcareous layers and with high fine fraction content (clay and silt) as is the one of the Grignon site. Indeed, alkalinity fosters the nitrification process and this range of $\mathrm{pH}$ is optimum for it to occur (e.g. Nieder and Benbi, 2008). A detailed description of the site can be found in Laville et al. (2009, 2011) and Loubet et al. (2011).

The field was cultivated with winter wheat (a mix of Atlass and Premio species), which was harvested on 3 August 2012 (16.7 $\mathrm{Mg} \mathrm{ha}^{-1}$ of dry matter). Cattle slurry was applied on the field with a trailing hose from 18 to 19 August 2012, at a rate of $42 \mathrm{~kg} \mathrm{Nha}^{-1}$ of which $78 \%$ was ammonium $\left(\mathrm{NH}_{4}^{+}\right)$. The slurry had a very low dry matter content of $3.2 \%$ and a $\mathrm{C} / \mathrm{N}$ ratio of 15.7. The total C applied was $666 \mathrm{~kg} \mathrm{Cha}^{-1}$. A gentle tillage was performed on 29 August 2012 to incorporate the crop and slurry residues and prepare the soil for oilseed rape sowing (variety Adriana) at a density of 35 plants per square metre. The crop developed slowly during the winter with a dry matter above ground (leaf area index) of $37 \mathrm{~g} \mathrm{~m}^{-2}\left(0.65 \mathrm{~m}^{2} \mathrm{~m}^{-2}\right)$ on 25 October 2012 and $104 \mathrm{~g} \mathrm{~m}^{-2}$ $\left(0.7 \mathrm{~m}^{2} \mathrm{~m}^{-2}\right)$ on the 18 February 2013 . The canopy height stayed below $10 \mathrm{~cm}$ during the whole winter. Ammonium nitrate pellets were applied on the oilseed-rape field on 20 February 2013 at a rate of $54 \mathrm{~kg} \mathrm{Nha}^{-1}$. Two selective herbicides were applied on the 2 (Springbok: $200 \mathrm{~g} \mathrm{~L}^{-1}$ of metazachlor; $200 \mathrm{~g} \mathrm{~L}^{-1}$ of DMTA-P at $3 \mathrm{~L} \mathrm{ha}^{-1}$ ) and 31 October 2012 (Devin/cycloxydim: $100 \mathrm{~g} \mathrm{~L}^{-1}$ at $1 \mathrm{~L} \mathrm{ha}^{-1}$ ) which only destroyed the weeds. In December 2012 slug-repellent pellets were applied.

\subsection{Micrometeorological and ancillary measurements}

Meteorological measurements included wind speed, wind direction, air and soil temperatures and humidity as well as rainfall, global, net and photosynthetic active radiation. The meteorological measurements were performed on a mast ( $3.17 \mathrm{~m}$ high) near the centre of the field and close to the flux measurement site (Fig. 1). Soil was sampled approximately once a month for water content, total nitrogen and mineral nitrogen analysis. Measurements are described in Loubet et al. (2011) and will not be detailed here.

A simplified sketch of the EC measurement system is shown in Fig. 1. Three-dimensional wind and temperature fluctuations were measured near the centre of the field at $3.17 \mathrm{~m}$ above ground by a sonic anemometer (Gill R3 3axis anemometer, Gill Instruments Limited, UK). A fast response open-path $\mathrm{CO}_{2} / \mathrm{H}_{2} \mathrm{O}$ infrared gas analyser (IRGA LI-7500A, LI-COR, USA) installed at a lateral distance of around $0.2 \mathrm{~m}$ to the sonic path measured $\mathrm{CO}_{2}$ and $\mathrm{H}_{2} \mathrm{O}$ fluctuations. $\mathrm{O}_{3}$ mixing ratios were measured by a highfrequency, dry chemiluminescence $\mathrm{O}_{3}$ detector (NOAA, USA) and its Teflon PFA inlet tube (length $=2.8 \mathrm{~m}$, internal diameter $=0.32 \mathrm{~mm}$ ) was positioned in-between the sonic path and the IRGA at a lower height. The high-frequency signals were recorded at $20 \mathrm{~Hz}$ by a Labview program developed in the laboratory. In accordance with Lee et al. (2015), highfrequency $(10 \mathrm{~Hz})$ time series of $\mathrm{NO}$ and $\mathrm{NO}_{2}$ were determined by two fast-response and closed-path chemiluminescence NO analysers (CLD 780TR, EcoPhysics, Switzerland), one being coupled to a photolytic converter (blue light converter, BLC, Droplet Measurement Technologies Inc, USA) for the detection of $\mathrm{NO}_{2}$ (see Fig. 1). The horizontal separation of the trace gas inlets from the sonic path was $20 \mathrm{~cm}$. Air was sampled through two heated and shaded PFA tubes with a length of $20 \mathrm{~m}$ and an inner diameter of $9.55 \mathrm{~mm}$. The first CLD was used for measuring NO and the second one connected to the BLC was used for detecting $\mathrm{NO}_{2}$. Conversion efficiencies for $\mathrm{NO}_{2}$ to $\mathrm{NO}$ of around $30 \%$ were achieved. The high-frequency signals of $\mathrm{NO}, \mathrm{NO}_{2}$ and $\mathrm{O}_{3}$ were calibrated with mixing ratios measured at $30 \mathrm{~min}$ time resolution by slow-response analysers (Thermo Scientific, Waltham, USA) (Fig. 1). These instruments were calibrated every 3 to 6 weeks using the gas-phase titration (GPT) method and 

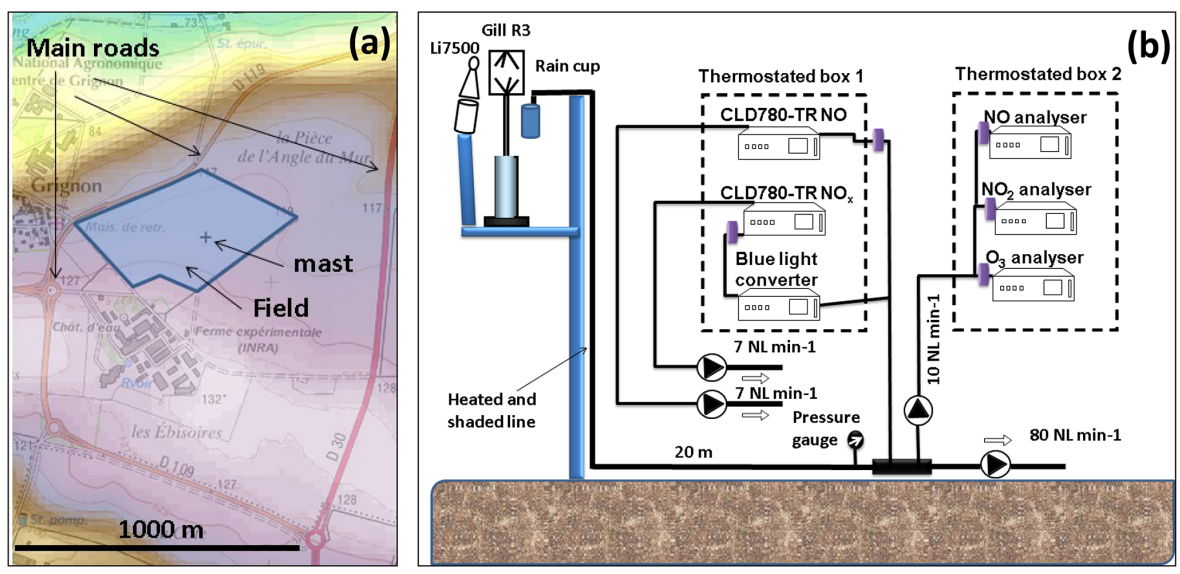

Figure 1. (a) Simplified map of the FR-GRI field site showing the mast and surrounding roads. The colours correspond to elevation. (b) Simplified sketch of the instrumental setup to measure EC fluxes. Gill R3 is the ultrasonic anemometer, $\mathrm{Li}_{7500}$ is the open-path infrared $\mathrm{CO}_{2}$ and $\mathrm{H}_{2} \mathrm{O}$ gas analyser, the rain cup is the air sampler for $\mathrm{NO}$ and $\mathrm{NO}_{2}$ detection. CLD780-TR NO and $\mathrm{NO}_{x}$ are the fast-response $\mathrm{NO}$ analysers (Ecophysics) operating in parallel, one connected to a BLC measuring $\mathrm{NO}+\alpha \mathrm{NO}_{2}$. The $\mathrm{NO}, \mathrm{NO}_{2}$ and $\mathrm{O}_{3}$ slow analysers $($ Thermo Scientific, Waltham, USA) are placed behind a Teflon pump ensuring atmospheric pressure at the inlet. A large pallet pump ensured a flow rate of $80 \mathrm{NL} \mathrm{min}^{-1}$ in the heated inlet line. Teflon filters $(1 \mu \mathrm{m})$ were installed at the front of the instrument inlets (purple cylinders).

a $17 \mathrm{ppm}$ NO standard (Air Liquide, FR). The fetch of the field site extended at least to $150 \mathrm{~m}$ in all directions and a footprint analysis showed that $90 \%$ of the time the entire field was in the footprint during neutral and moderately stable or unstable conditions (Loubet et al., 2011). NO and $\mathrm{O}_{3}$ fast sensors were functioning during the whole campaign (7 August 2012 to 13 March 2013) together with NO, $\mathrm{NO}_{2}$ and $\mathrm{O}_{3}$ slow-response analysers and the meteorological station. High-frequency $\mathrm{NO}_{2}$ measurement was performed from 14 August to 30 September 2012. In this study we focus on two periods: (1) from 14 to 29 August 2012 during which all fluxes were measured and NO fluxes were the highest, in order to investigate the interactions between the fluxes and mixing ratios of the $\mathrm{NO}-\mathrm{NO}_{2}-\mathrm{O}_{3}$ triad, and (2) over the whole period for NO fluxes analysis.

\subsection{Eddy covariance flux computations}

The turbulent fluxes were computed as the covariance between the fluctuations of the scalar of interest and the vertical component of the wind. As the EC method and its theoretical background are described in the literature - e.g. Foken (2008) - details will not be provided here.

For closed-path sensors ( $\mathrm{NO}, \mathrm{NO}_{2}$ and $\mathrm{O}_{3}$ ), the lag time between $w^{\prime}$ and the dry mole fraction $\chi$ had to be determined. This was done by searching for the maximum of the covariance function

$\left(\chi \overline{w^{\prime}(t)^{\prime}(t-\operatorname{lag})}\right.$.

The lag for NO was $3.1 \mathrm{~s}[2.4-3.65 \mathrm{~s}]\left(Q_{50}\left[Q_{25}-Q_{75}\right]\right)$, for $\mathrm{NO}_{2}$ it was $4.0 \mathrm{~s}[3.65-4.55 \mathrm{~s}]$ and for $\mathrm{O}_{3}$ it was $2.9 \mathrm{~s}$ [2.5$3.25 \mathrm{~s}]$. The lag was filtered for outliers (points outside of median lag \pm standard deviation were considered as outliers) and the covariance was computed as the value of the covariance function at the filtered lag.

As fast-response sensors for $\mathrm{NO}, \mathrm{NO}_{2}$ and $\mathrm{O}_{3}$ were not absolute, the fluxes were computed following the ratio method for $\mathrm{O}_{3}$ described by Muller et al. (2010), and in accordance with Lee et al. (2015) for $\mathrm{NO}$ and $\mathrm{NO}_{2}$ :

$$
\begin{aligned}
\chi F_{\mathrm{O}_{3}} & =\frac{\overline{\chi_{\mathrm{O}_{3}}}}{V_{\mathrm{dry}}} \frac{\overline{w^{\prime} \mathrm{O}_{3}{ }^{\prime}}}{\overline{\mathrm{O}_{3}}}, \\
F_{\mathrm{NO}} & =\frac{\overline{w^{\prime} \mathrm{NO}^{\prime}}}{S_{\mathrm{NO}} V_{\mathrm{dry}}}, \\
F_{\mathrm{NO}_{2}} & =\frac{1}{\alpha V_{\mathrm{dry}}}\left(\frac{\overline{w^{\prime} \mathrm{NO}_{x}{ }^{\prime}}}{S_{\mathrm{NO}_{x}}}-\frac{\overline{w^{\prime} \mathrm{NO}^{\prime}}}{S_{\mathrm{NO}}}\right),
\end{aligned}
$$

where $\mathrm{O}_{3}$ (in $\mathrm{mV}$ ), $\mathrm{NO}$ and $\mathrm{NO}_{x}$ (in counts $\mathrm{s}^{-1}$ ) are the uncalibrated fast signals, $\overline{\chi_{\mathrm{O}_{3}}}$ is the $30 \mathrm{~min}$ average of the slow-sensor reference $\mathrm{O}_{3}$ mixing ratio (in ppb), while $S_{\mathrm{NO}}$ and $\mathrm{S}_{\mathrm{NO}_{2}}$ are the sensitivity of the analysers (in counts $\mathrm{s}^{-1} \mathrm{ppb}^{-1}$ ). The $\alpha$ is the blue light converter conversion efficiency, and $V_{\text {dry }}$ is the molar volume of dry air (in $\mathrm{m}^{3} \mathrm{~mol}^{-1}$ ). All fluxes (momentum, heat, $\mathrm{CO}_{2}, \mathrm{H}_{2} \mathrm{O}$, $\mathrm{NO}, \mathrm{NO}_{2}, \mathrm{O}_{3}$ ) were computed by the EddyPro softwareversion 5 (http://www.licor.com/eddypro) and final flux data were averaged for $30 \mathrm{~min}$ intervals. Evaluation methodologies from the CarboEurope project were applied - see Aubinet et al. (2000) and Loubet et al. (2011).

\subsection{Spectral corrections and flux uncertainties}

Spectral attenuation of the flux is due to differential transport time of the compound in the tube and interaction with tube walls and filter surfaces (Massman and Ibrom, 2008). 


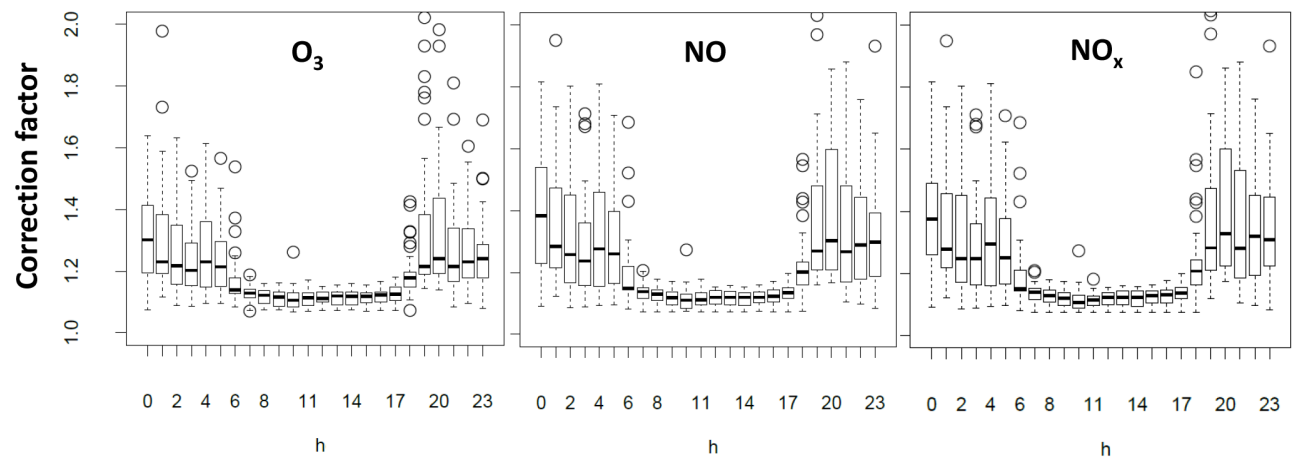

Figure 2. Hourly averaged high-frequency loss correction factors for $\mathrm{O}_{3}$, $\mathrm{NO}$ and $\mathrm{NO}_{x}$ over the 15 August-7 September 2012 period determined with the in situ ogive method. The corrected flux equals the measured flux multiplied by the correction factor. Black bars are medians, boxes show the interquartile, error bars show the minimum and maximum of the whisker and empty dots shows the outliers.

We tend to minimise this effect by ensuring a large flow rate in the tubes with a Reynolds number well above the critical threshold for turbulence - see Lenschow and Raupach (1991) - as well as heating the tubes to around $5{ }^{\circ} \mathrm{C}$ above ambient temperature. The residence time of the air samples inside the tubing was around $1 \mathrm{~s}$, ensuring low chemical conversions, and the Reynolds number was 11700 , hence largely in the turbulent range $(R e>4000)$. However, water vapour interaction is still expected, and sensor separation also generates high-frequency losses.

The $\mathrm{NO}, \mathrm{NO}_{2}$ and $\mathrm{O}_{3}$ random instrument noises were estimated as the $1 \sigma$ random uncertainty of the signals as in Lenschow et al. (2000), Langford et al. (2015) and Mauder et al. (2008). This is assumed to be "white noise" and hence uncorrelated with itself apart from at lag $=0 \mathrm{~s}$. It is therefore estimated as the difference between the autocorrelation at lag $=0 \mathrm{~s}$ and at lag $= \pm 0.05 \mathrm{~s}$. The flux random uncertainty was itself evaluated as the covariance detection limit. It was determined as the root mean square error of the covariance function over $60 \mathrm{~s}$ periods at lag times well away from the position of the time lag. In practice, these were taken at lags larger than $120 \mathrm{~s}$ as absolute values, as proposed by Langford et al. (2015).

\subsection{Chemical reactions, timescales and flux divergence}

Chemical reactions between $\mathrm{NO}, \mathrm{NO}_{2}$ and $\mathrm{O}_{3}$ are important to consider when interpreting the measured fluxes as they can affect the fluxes above the ground. A common way to determine whether these reactions may indeed affect the flux is through comparison of chemical and transport timescales. Details of the reactions rates, timescales and flux divergence calculations are given in Sects. S1-S3 in the Supplement.

\section{Results and discussion}

\subsection{Quality check and uncertainties in $\mathrm{NO}, \mathrm{NO}_{2}$ and $\mathrm{O}_{3}$ flux measurements}

$\mathrm{NO}_{x}$ and $\mathrm{O}_{3}$ half-hourly fluxes were filtered by the quality check test included in EddyPro (http://www.licor.com/ eddypro), according to the 0-1-2 labelling proposed by Mauder and Foken (2006), which includes tests for stationarity and for well-developed turbulence. As recommended in the framework of the CarboEurope project, we discarded fluxes with a quality check index value of 2 . This led to keeping 74, 84 and $76 \%$ of the records for $\mathrm{NO}, \mathrm{O}_{3}$ and $\mathrm{NO}_{2}$, respectively. The total records of $\mathrm{NO}$ and $\mathrm{O}_{3}$ half-hourly fluxes were 11329 (from 7 August 2012 to 13 March 2013), while for $\mathrm{NO}_{2}$ they were 2257 (during the period 14 August to 30 September 2012).

The largest systematic uncertainties were the highfrequency losses, which were estimated with the in-situ ogive method (Ammann et al., 2006), and amounted to $10 \%$ for $\mathrm{O}_{3}, 20 \%$ for $\mathrm{NO}$ and $30 \%$ for $\mathrm{NO}_{2}$ on average over the August-September period (when all fluxes were measured, see Fig. 2). As a bias, they can be corrected for, as in the following sections of this paper.

The second largest uncertainties were the random uncertainties which were lower than $20 \%$ in most cases for $\mathrm{O}_{3}, \mathrm{NO}$ (and similar to $\mathrm{H}_{2} \mathrm{O}$ ) and around 30 to $40 \%$ for $\mathrm{NO}_{2}$ (Fig. 3). For $\mathrm{NO}$ and $\mathrm{NO}_{2}$ the random uncertainties peaked during the morning traffic hour around 06:00-08:00 UTC, which is explained by the non-stationarity generated by the local traffic on the mixing ratios. Hence overall the EC method proved to be usable for measuring NO fluxes over part of the season with an overall uncertainty similar to $\mathrm{H}_{2} \mathrm{O}$. A higher random uncertainty was found for $\mathrm{NO}_{2}$ fluxes which were smaller than NO fluxes and with a relatively low conversion ratio from $\mathrm{NO}_{2}$ to $\mathrm{NO}(30 \%)$. 


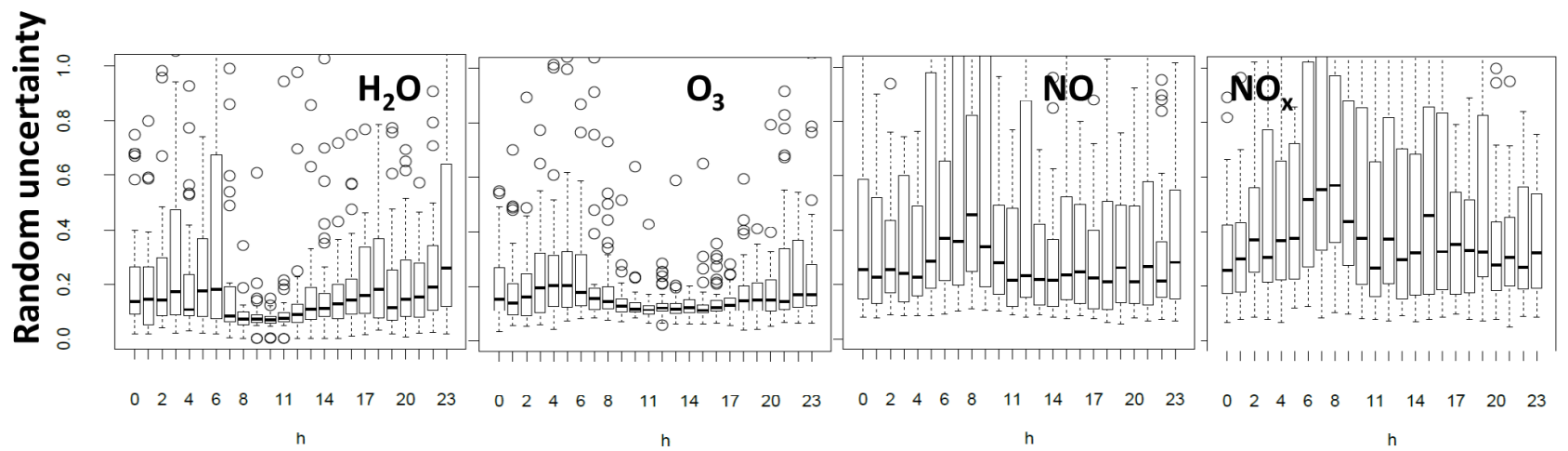

Figure 3. Daily variations of the ratio of the random uncertainty to the flux for $\mathrm{H}_{2} \mathrm{O}, \mathrm{O}_{3}, \mathrm{NO}$ and $\mathrm{NO}_{x}$ during August 2012 (15 August to 9 September). Black bars are medians, boxes show the interquartile, error bars show the minimum and maximum of the whisker and empty dots shows the outliers.

\subsection{Meteorological conditions}

Daily averages of the air temperature decreased during the measurement period, starting from about $20^{\circ} \mathrm{C}$ in summer and reaching minima around $-5^{\circ} \mathrm{C}$ from December to March. Daily averages of global radiation decreased from $250 \mathrm{~W} \mathrm{~m}^{-2}$ in August to around $0 \mathrm{~W} \mathrm{~m}^{-2}$ in December, back to around $150 \mathrm{~W} \mathrm{~m}^{-2}$ by the end of March. The daily average of the relative humidity was around $65 \%$ in August and September, and it increased to about $85 \%$ for the rest of the period (Fig. 4). The wettest period was between October and November, and cumulative rain was $319 \mathrm{~mm}$ over the 7-month period, which is quite high. The prevailing wind direction was southwest while the most intense winds were observed from north and south (Fig. S2 in the Supplement). Figure S2 also shows that wind regimes were quite different in summer and winter: prevailing wind directions during August and February were from the southwest and northeast, respectively. Soil water content (SWC) ranged between 20 and $40 \%$ (volume) (Fig. 4), with a long period between October and January with values around $28 \%$, and increased further in January to $35 \%$, with sharp decrease during some periods.

\subsection{Seasonal dynamics and diurnal cycles of the NO, $\mathrm{NO}_{2}$ and $\mathrm{O}_{3}$ fluxes above the crop rotation}

\subsubsection{Seasonal dynamics of $\mathrm{NO}-\mathrm{NO}_{2}-\mathrm{O}_{3}$ mixing ratios}

Average daily $\mathrm{NO}, \mathrm{NO}_{2}$ and $\mathrm{O}_{3}$ mixing ratios were 3.6, 6.9 and $24.8 \mathrm{ppb}$, respectively. The $\mathrm{NO}$ and $\mathrm{NO}_{2}$ mixing ratios were higher when winds blew from the east (from the direction of Paris), while $\mathrm{O}_{3}$ showed the opposite behaviour, which can be explained by depletion of $\mathrm{O}_{3}$ by $\mathrm{NO}$ sources from the surrounding traffic (as shown in Fig. S2) and by reactions (Sects. S1-S2). Daily $\mathrm{NO}_{2} / \mathrm{NO}_{x}$ ratios were on average $66 \%$, which is typical for traffic and urban pollution (Carslaw, 2005; Minoura and Ito, 2010), and ranged from 4 to $93 \%$ during the entire period. The $\mathrm{NO}_{2}$ mixing ratios were significantly higher (Student $t$ test $p$ value lower than $8 \times 10^{-11}$ ) than the NO mixing ratios in August and early September, end of January and mid-February, and end of March. During sporadic episodes, NO peaks were of the same order or even higher than $\mathrm{NO}_{2}$ peaks (Fig. 4).

\subsubsection{Seasonal dynamics of $\mathrm{NO}, \mathrm{NO}_{2}$ and $\mathrm{O}_{3}$ fluxes}

The daily averaged NO fluxes were very small, except during a period of strong emission following organic fertilisation over two days in August (18-19 August 2012), with maximum daily average fluxes of around $1.5 \mathrm{nmol} \mathrm{m}^{-2} \mathrm{~s}^{-1}$ (Fig. 4). Other emission episodes, including mineral fertilisation in February (20 February 2013), were characterised by mean daily fluxes below $0.5 \mathrm{nmol} \mathrm{m}^{-2} \mathrm{~s}^{-1}$. The NO fluxes were slightly negative for some events $\left(Q_{25}, Q_{50}\right.$ and $Q_{75}$ equal to -0.013 , 0.031 and $0.11 \mathrm{nmol} \mathrm{m}^{-2} \mathrm{~s}^{-1}$, Fig. S3). The $\mathrm{O}_{3}$ fluxes ranged between -13.8 and $0 \mathrm{nmol} \mathrm{m}^{-2} \mathrm{~s}^{-1}$, and averaged to $-3.12 \mathrm{nmol} \mathrm{m}^{-2} \mathrm{~s}^{-1}$. The largest $\mathrm{O}_{3}$ deposition fluxes were observed following organic fertilisation in August, and were correlated with the highest $\mathrm{NO}$ emissions. This period also corresponded to large daily $\mathrm{O}_{3}$ mixing ratios (Fig. 4). The $\mathrm{NO}_{2}$ fluxes were only measured during the first one and a half months (14 August to 30 September 2012) and were mostly negative (indicating deposition), except during the first week following organic fertilisation $\left(Q_{25}, Q_{50}\right.$ and $Q_{75}$ equal $-0.11,-0.07$ and $0.08 \mathrm{nmol} \mathrm{m}^{-2} \mathrm{~s}^{-1}$ ) (Fig. S3). $\mathrm{O}_{3}$ fluxes were in the same range of magnitude, typically between -20 and $0 \mathrm{nmol} \mathrm{m}^{-2} \mathrm{~s}^{-1}$, as those reported by previous studies at the same site (Stella et al., 2013b, 2011b; Tuzet et al., 2011) and in the literature over various canopies such as grassland (Stella et al., 2013a), barley (Gerosa et al., 2004), potato field (Coyle et al., 2009) or forests (Fares et al., 2010; Gerosa et al., 2005), although $\mathrm{O}_{3}$ flux magnitude is sharply dependent on local $\mathrm{O}_{3}$ mixing ratio. We found similar magnitudes of ozone fluxes in August and September as 


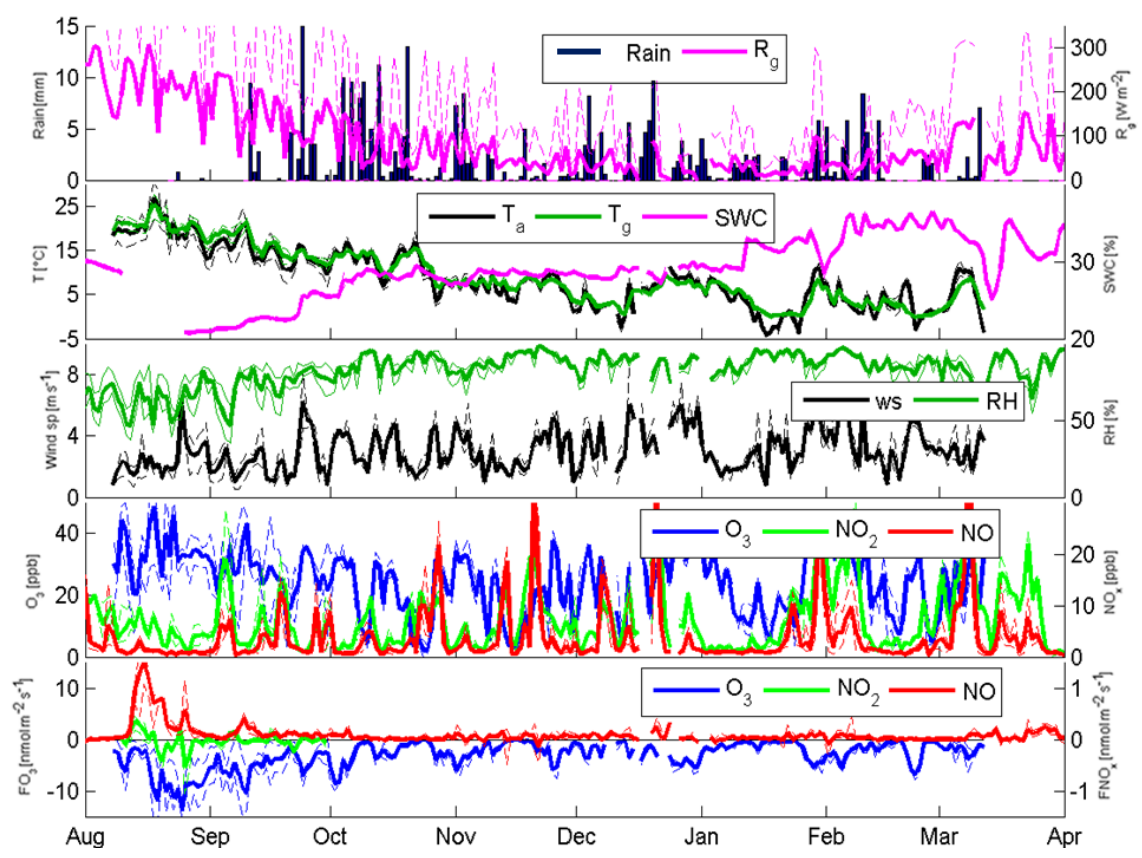

Figure 4. Meteorological and soil conditions (daily averages, sums for rainfall), $\mathrm{NO}, \mathrm{NO}_{2}$ and $\mathrm{O}_{3}$ mixing ratios and fluxes during the entire measurement period from 7 August 2012 to 13 March 2013 at the Grignon field site. Averages for night-time and daytime are also given as dotted lines. $R_{\mathrm{g}}$ is the global radiation, $T_{\mathrm{a}}$ and $T_{\mathrm{g}}$ the air and ground temperature, SWC the soil water content, ws the wind speed, RH the air relative humidity.

those reported by Stella et al. (2013a) over a meadow during the summer. We also found similar nocturnal $\mathrm{O}_{3}$ deposition velocity as found by Stella et al. (2011a) over bare soil during summer, but with a higher daily maximum $\left(0.8 \mathrm{~cm} \mathrm{~s}^{-1}\right.$ instead of $0.5-0.6 \mathrm{~cm} \mathrm{~s}^{-1}$ ). Seasonal and daily dynamics of $\mathrm{O}_{3}$ deposition velocity are shown in Fig. 5. We further find a similar midday magnitude as Stella et al. (2011a) found in April with wetter soils. Night-time ozone deposition velocity did not go lower than around $0.2 \mathrm{~cm} \mathrm{~s}^{-1}$ in our study, as also found by Zhu et al. (2015) over a growing wheat in China, Stella et al. (2011a) over bare soil in summer, and Lamaud et al. (2009) over maize. These authors as well as Huang et al. (2016) clearly show that this is due to non-stomatal deposition being primarily driven by $u_{*}$ which does not reach zero at night during these periods. We can hence conclude that we found consistent ozone deposition in August and September compared to other studies at that site or in other geographical areas. When compared to previous years at the same site the deposition velocity measured during the winter in this study was clearly smaller. We interpret this as being primarily due to $u_{*}$ being smaller that winter compared to other winters, as well as due to a bad development of the winter crop due to soil drought in September (SWC $=20 \%$ in the $15 \mathrm{~cm}$ horizon).

\subsubsection{Comparison of ozone fluxes to the Stella et al. (2011a) parameterisation over soil}

In order to compare to previous studies of ozone deposition onto bare soil on the same site, we have calculated the soil surface resistance as in Stella et al. (2011a) and deduced the ozone deposition velocity as $V_{\mathrm{dO}_{3}}=\left(R_{\mathrm{SoilO}_{3}}+R_{\mathrm{bO}_{3}}+R_{\mathrm{a}}\left(z_{\mathrm{ref}}\right)\right)^{-1}$. In this way, we can compare the two studies while excluding any confounding factors (roughness and turbulent exchange intensity). We can see in Fig. 6a that the measured ozone deposition velocity during August follows the parameterisation of Stella et al. (2011a) most of the time except for some days including 18 and 19 August which correspond to slurry application and 24,25 , and 26 August, which follow a small rainfall. We also see an overestimation of the Stella parameterisation before the 18 August, which we interpret as being due to the straw and wheat residues being present on the ground before slurry incorporation. This comparison hence demonstrates that the ozone deposition was indeed increased slightly following slurry application and subsequently following rainfall. This may be either due to a physical reason (increased surface exchange on the soil due to tillage or humidity change due to slurry) or a chemical reason (surface reactivity changes due to added organic matter or volatile organic compound (VOC) emissions from the slurry). Figure $6 \mathrm{~b}$ further shows that the main differences are observed for wet soils and relatively low 


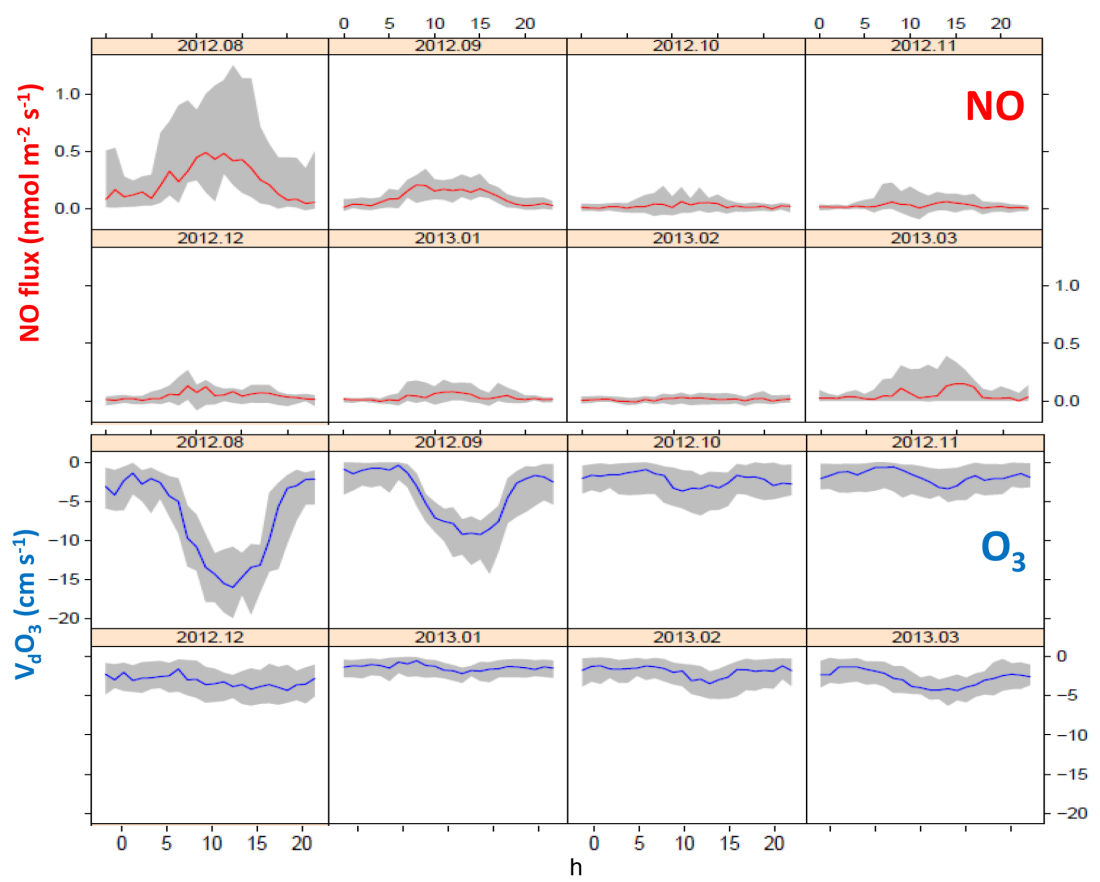

Figure 5. Seasonal changes of ozone deposition velocity $V_{\mathrm{dO}_{3}}$ and $\mathrm{NO}$ fluxes. Blue lines show median and grey area inter-quantiles.

temperatures (this is after rainfall) and to a lesser extent for drier and hotter situations (following slurry spreading).

\subsubsection{Diurnal cycles of mixing ratios and fluxes over periods of interest}

$\mathrm{O}_{3}$ mixing ratios exhibited a typical diurnal cycle that was governed by photochemistry and convective mixing within the boundary layer and from the free troposphere during daytime. It started to increase with sunlight around 07:00, and declined in the evening starting from 18:00 due to lack of photochemical formation in the absence of sunlight, as well as deposition and destruction with $\mathrm{NO}$ in this high $\mathrm{NO}_{x}$ emission area. In general, NO mixing ratios featured a marked peak in the early morning and remained high until around 13:00 UTC (Fig. 7b). During the early afternoon, the $\mathrm{O}_{3}$ increase was correlated with the $\mathrm{NO}$ decrease. $\mathrm{NO}_{2}$ mixing ratios showed a bi-modal diurnal cycle with its maxima in correspondence with morning and evening traffic peaks, i.e. around 06:00 and 19:00.

The NO fluxes also showed a diurnal cycle similar to the one of soil temperature with an emission peak around 00:00 (Fig. 7a and b). This suggests that NO emissions are related to nitrification, for which the emission rate is an exponential function of soil temperature (Henault et al., 2005). This was already shown for the Grignon soil by Laville et al. (2011). The fact that NO fluxes decrease earlier than soil temperature is most likely due to titration of $\mathrm{NO}$ by $\mathrm{O}_{3}$ in the late morning and early afternoon, causing the NO emissions at the reference height to be reduced with respect to ground emissions.
After correction for chemical reactions the $\mathrm{NO}$ emissions diurnal cycle is indeed at a peak later in the day, more in phase with ground temperature (see Fig. 11). This is also indicated by the positive $\mathrm{NO}_{2}$ flux observed during the same time of the day. The $\mathrm{O}_{3}$ flux was mainly negative (deposition) and follows the diurnal dynamics of measured mixing ratios. In terms of deposition velocity, the ozone deposition velocity followed a clear diurnal cycle with a maximum during the day and a minimum at night. The measured $\mathrm{NO}_{2}$ deposition velocity showed slightly negative values, but slightly positive ones when corrected for reactions with $\mathrm{NO}$ and $\mathrm{O}_{3}$.

\subsection{Influence of organic and mineral fertilisations on NO emissions}

The NO flux averaged over the whole period was $0.09 \mathrm{nmol} \mathrm{m}^{-2} \mathrm{~s}^{-1}$ (mean), which is in the range of previous findings for the same site. Laville et al. (2011) and Loubet et al. (2011) reported yearly averaged NO fluxes varying between 0.07 and $0.15 \mathrm{nmol} \mathrm{m}^{-2} \mathrm{~s}^{-1}$ for 2007-2009. The NO flux distribution was shifted towards positive values after the organic fertilisation in August (Fig. S3), with the mean NO flux during the 2 weeks following the fertilisation $\left(0.49 \mathrm{nmol} \mathrm{m}^{-2} \mathrm{~s}^{-1}\right)$ being six times larger than the one for the whole period. For the same period, the ozone flux distribution was shifted towards more negative values. Figure S3 also shows that flux distributions after mineral fertilisation do not differ much from the ones relative to the whole period. During the 2 weeks following the February mineral fertilisation the NO flux increased less and was only 1.7 larger than 

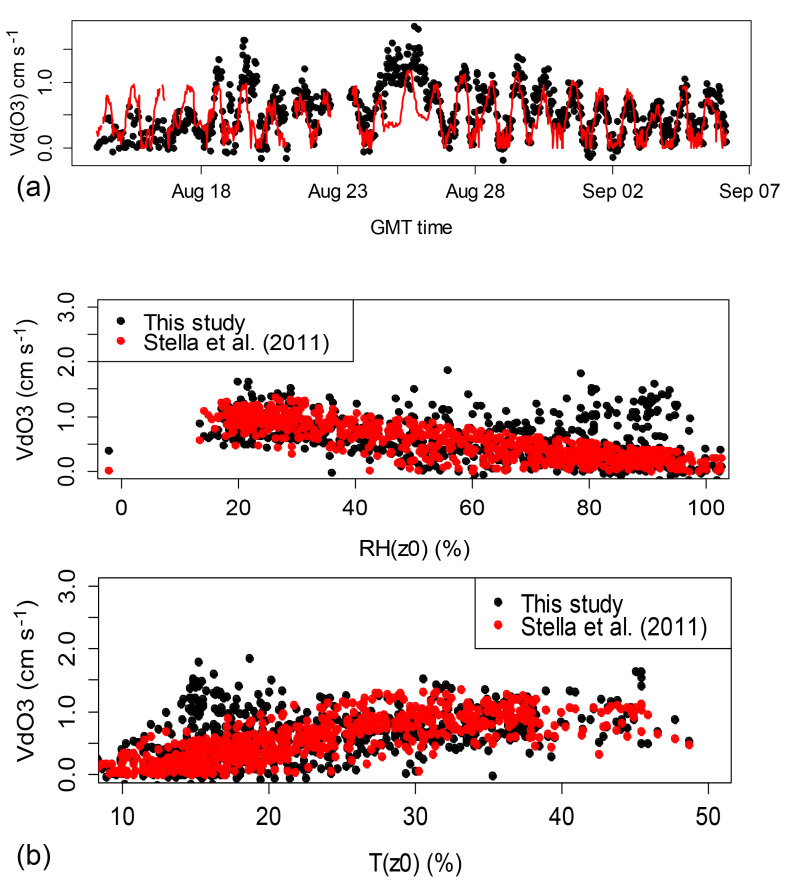

Figure 6. (a) Comparison of ozone deposition velocity from this study (black dots), and from the parameterisation of Stella et al. (2011a) (red line) based on surface temperature. (b) Response of ozone deposition velocity to surface humidity $\mathrm{RH}\left(z_{0}\right)$ and surface temperature $T\left(z_{0}\right)$. Shown are data from this study and from the parameterisation of Stella et al. (2011a). The period covered is from 14 August to 6 September which is before and after slurry spreading and corresponds to Fig. S5.

over the whole period $\left(0.14 \mathrm{nmol} \mathrm{m}^{-2} \mathrm{~s}^{-1}\right)$. These numbers are also in line with those reported following fertilisation on the same soil in the 2007-2009 period by Laville et al. (2011) and Loubet et al. (2011), which also showed some periods with slightly negative NO fluxes. Stella et al. (2012) measured a larger peak of $\mathrm{NO}$ emissions following slurry spreading, but only lasting 2 to 3 days, which was probably due to a drier soil in our study compared to Stella et al. (2012).

Following the slurry application, the NO emissions amounted to $0.1 \mathrm{~kg} \mathrm{Nha}^{-1}$, which represents $0.24 \%$ of the applied nitrogen $(42 \mathrm{~kg} \mathrm{~N})$. Following the mineral fertilisation, the $\mathrm{NO}$ emissions amounted to $0.02 \mathrm{~kg} \mathrm{~N} \mathrm{ha}^{-1}$, which represents $0.037 \%$ of the applied nitrogen $(54 \mathrm{~kg} \mathrm{~N})$. Over the whole period from August 2012 to March 2013, we evaluate a loss of $0.26 \mathrm{~kg} \mathrm{Nha}^{-1}$. With a total $\mathrm{N}$ input of $96 \mathrm{~kg} \mathrm{Nha}^{-1}$, this gives an estimate of the NO emission factor of $0.27 \%$, which is similar to values reported earlier for the same site (Laville et al., 2011) but one order of magnitude larger than the EMEP/IPCC default value of 0.04. Nevertheless, this is an average value calculated with the Tier 1 approach, which does not take into account correction factors depending on soil $\mathrm{pH}$ or fertiliser type. This more detailed approach, the Tier 2, has not been developed for NO (EEA, 2016).

The reasons for lower emissions following winter mineral fertilisation than following summer manure application are manifold. Even if the amount of applied nitrogen was similar for the two cases ( 42 and $54 \mathrm{~kg} \mathrm{Nha}^{-1}$ ), meteorological and soil conditions were much more favourable for nitrification in summer than in winter (Davidson, 1992; Williams and Fehsenfeld, 1991). Indeed, NO emissions from agricultural soils are primarily the by-products of nitrification, and this hypothesis was tested for the Grignon site by Laville et al. (2011). Nitrification is inhibited by low soil temperature and high water content that causes anoxia. Soil temperature was much lower in February than in August (2.5 compared to $20^{\circ} \mathrm{C}$ on average). February was particularly humid, with a total precipitation of $10 \mathrm{~mm}$, while in August no significant rain event occurred after the first week. In this period indeed, the soil was only humidified by the organic manure supply (on a $4.8 \mathrm{~mm}$ thick layer) that was applied on a dry soil. The soil water content at $5 \mathrm{~cm}$ depth in September 2012 was around $21 \%$ in volume, while in February it was $33 \%$ in volume. These two factors led to more favourable conditions for nitrification in August than in February.

\subsection{Influence of surrounding roads on the measured fluxes and concentrations of the $\mathrm{NO}-\mathrm{NO}_{2}-\mathrm{O}_{3}$ triad}

Using the FIDES flux and concentration footprint model (Loubet et al., 2010) we evaluated the footprint of nearby roads. Overall the flux footprint from the nearby roads was smaller than $1 \%$ (which means that only $1 \%$ of the road emissions contributes to the flux at the mast) most of the time, but the concentration footprint reaches up to $10 \%$ during some episodes, with separate roads contributing differently depending on the period (Fig. S1). Assuming a conservative emission of $250 \mathrm{mg} \mathrm{km}^{-1}$ vehicle $^{-1}$ and an average vehicle count of 10000 vehicles day ${ }^{-1}$ (2010 counts, "Statistiques du département des Yvelines pour 2010" ranges between 5000 and 15000 ), we evaluate that the roads contribute from 4 to $40 \%$ to the measured fluxes. However, since vehicles emissions of $\mathrm{NO}_{x}$ have a sporadic nature, 10000 vehicles day ${ }^{-1}$ means a maximum of $\sim 1$ vehicle every $2 \mathrm{~s}$ (if we consider, conservatively, that most of the traffic is condensed during $9 \mathrm{~h}$ only). These vehicles are also moving at about $90 \mathrm{~km} \mathrm{~h}^{-1}\left(25 \mathrm{~m} \mathrm{~s}^{-1}\right)$, hence leading to a moving point source of $\mathrm{NO}_{x}$. We therefore expect that the signal of this moving and sporadic source is not captured by the EC method, and would be filtered out by despiking and flux calculation procedures (Foken, 2008; Mahrt, 2010).

\subsection{Chemical interactions: the $\mathrm{NO}-\mathrm{NO}_{2}-\mathrm{O}_{3}$ triad and effect on the fluxes}

In order to investigate the interactions between the fluxes and mixing ratios of the NO- $\mathrm{NO}_{2}-\mathrm{O}_{3}$ triad, we focus on the pe- 


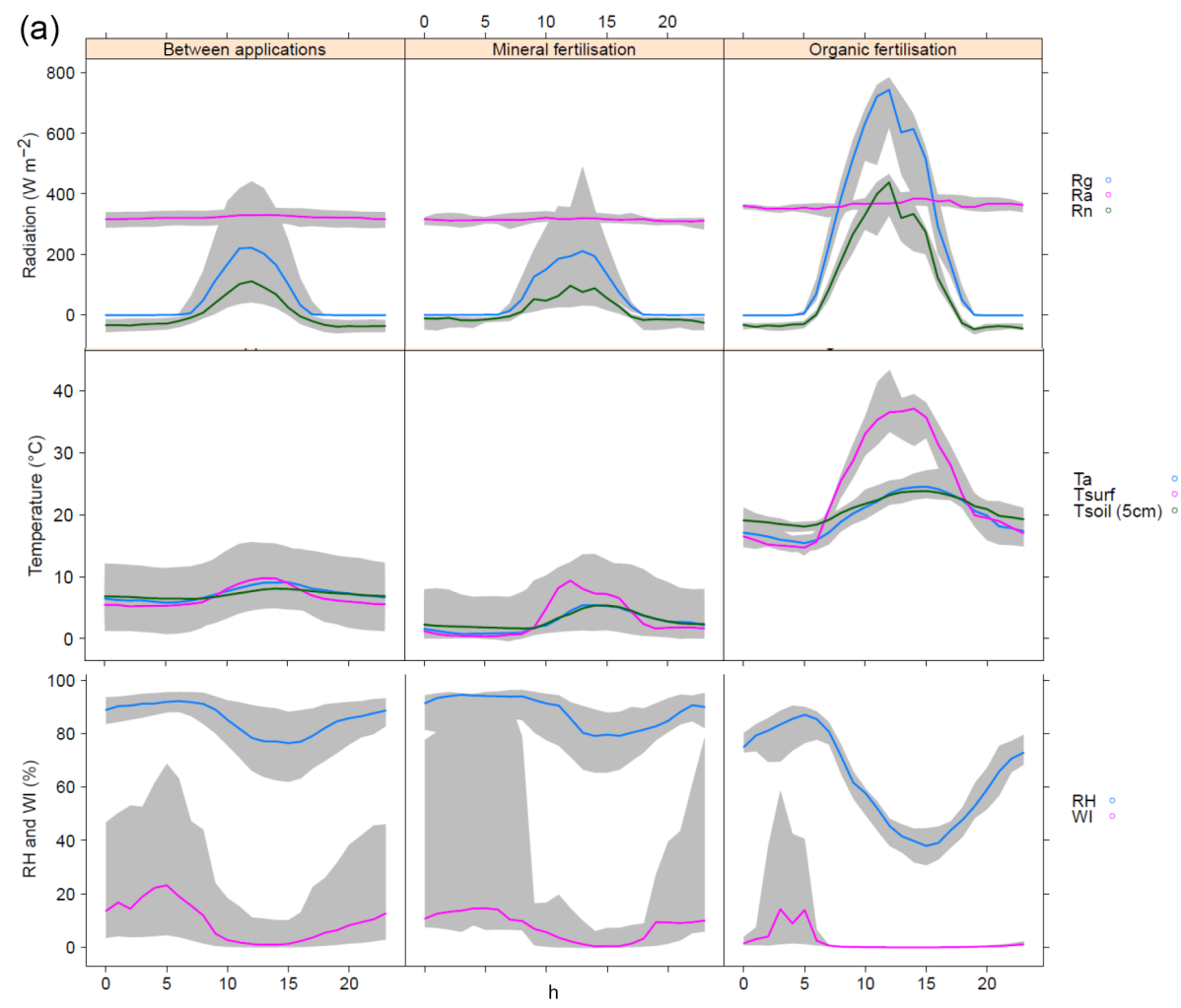

(b)

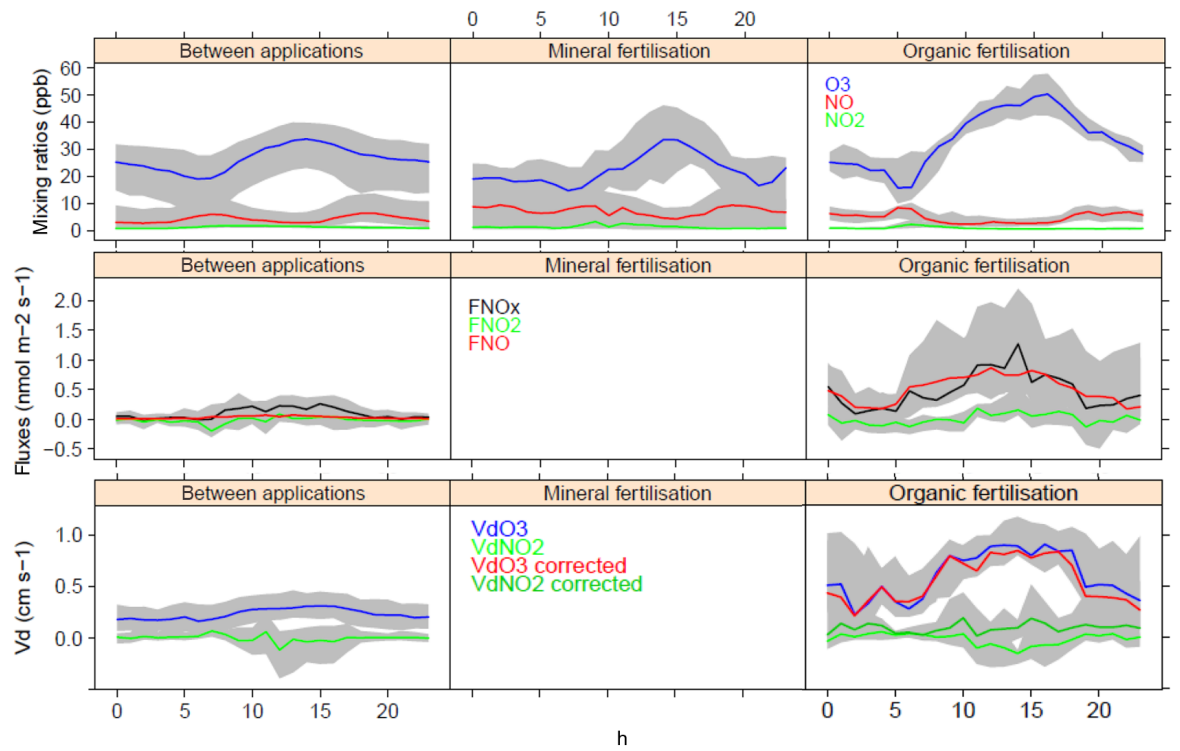

Figure 7. (a) Diurnal cycles of global irradiance and net radiation, air and soil temperatures, relative humidity and wetness index averaged over the three periods of interest at the Grignon field site. The shaded areas represent the interquartile range. (b) Diurnal cycles of $\mathrm{NO}, \mathrm{NO}_{2}$ and $\mathrm{O}_{3}$ mixing ratios and fluxes as well as the deposition velocities of $\mathrm{NO}_{2}$ and $\mathrm{O}_{3}$, averaged over the three periods of interest at the Grignon field site. The shaded areas represent the interquartile range. The deposition velocity of $\mathrm{NO}_{2}$ and $\mathrm{O}_{3}$ based on the fluxes accounting for chemical reactions above ground are also shown $\left(V_{\mathrm{dO}_{3}}\right.$ and $V_{\mathrm{dNO}_{2}}$ corrected). 


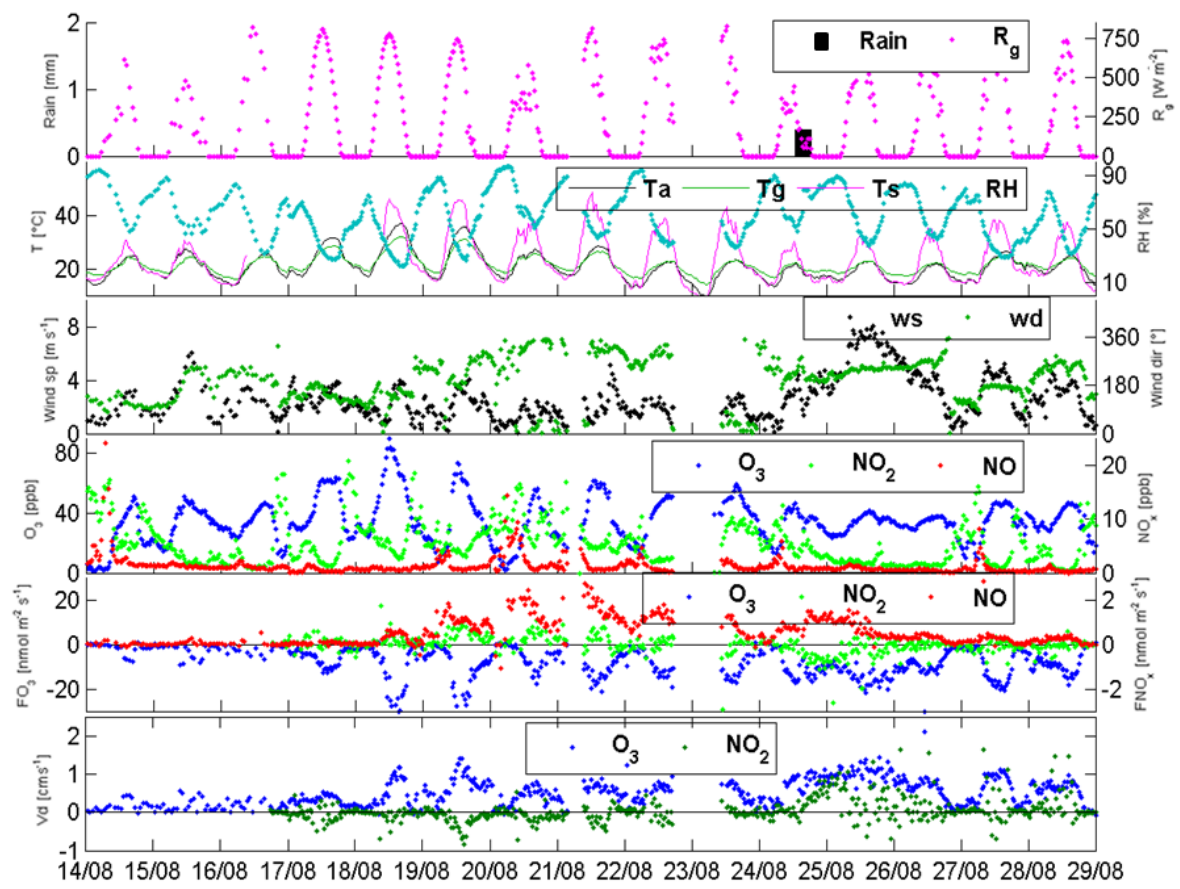

Figure 8. Meteorological variables and $\mathrm{NO}_{x}-\mathrm{O}_{3}$ mixing ratios and fluxes measured during the period 14 to 29 August 2012 at the Grignon field site. Ticks on the $x$ axis correspond to midnight.

riod from 14 to 29 August 2012, during which all fluxes were measured and NO fluxes were the highest.

The 2 weeks following the organic manure application (from 18 to 19 August) are characterised by hot sunny days, with maximal global radiation above $800 \mathrm{~W} \mathrm{~m}^{-2}$, except for 24 August when the only rain event occurred (Fig. 8). The period of 18 to 23 August was the warmest, with soil surface temperatures above $40{ }^{\circ} \mathrm{C}$ at noon during most days, while the air temperature decreased from around 35 to around $20^{\circ} \mathrm{C}$ during the same period. The soil temperature at $5 \mathrm{~cm}$ depth followed the same trend, but with a lower daily maximum and a higher night-time minimum. Due to sensor breakdown the soil water content was not measured during this period. The small latent heat flux (LE) after the $19 \mathrm{Au}-$ gust, ( $17 \mathrm{~W} \mathrm{~m}^{-2}$ on average between 19 and 31 August) the large sensible heat flux ( $60 \mathrm{~W} \mathrm{~m}^{-2}$ on average) and radiation $\left(212 \mathrm{~W} \mathrm{~m}^{-2}\right.$ on average) indicate that the soil humidity of the top soil layer was low. Hence, we assume that the SWC was probably similar to what was measured in September (around 20\% in volume), which is ideal for nitrification to occur (Laville et al., 2011; Oswald et al., 2013).

The 18 August was the first day when NO emissions from the soil occurred. The emissions lasted around 2 weeks following the organic fertilisation (Fig. 4), during which the NO flux during daytime exceeded $0.5 \mathrm{nmol} \mathrm{m}^{-2} \mathrm{~s}^{-1}$, peaking around 00:00. The nocturnal NO flux usually decreased to zero, except for the night of 25 August, characterised by strong winds (Fig. 8). The maximum of the NO emissions was $2.7 \mathrm{nmol} \mathrm{m} \mathrm{m}^{-2} \mathrm{~s}^{-1}$ observed 6 days after fertilisation on 21 August.

The $\mathrm{NO}_{2}$ flux daily pattern was different during the two weeks following organic manure application compared to the period before (Fig. 8). It was in general positive during the day and around zero at night during the period from 18 to 29 August, except for the night of 25 August when it was large and negative. Positive $\mathrm{NO}_{2}$ fluxes might be explained by chemical reactions between $\mathrm{NO}$ and $\mathrm{O}_{3}$ in the surface layer (De Arellano et al., 1993), which will be discussed in the next section.

The $\mathrm{O}_{3}$ flux was also significantly higher (Student $t$ test $p$ value lower than $2 \times 10^{-16}$ ) following organic fertilisation (mean $-10.7 \mathrm{nmol} \mathrm{m}^{-2} \mathrm{~s}^{-1}$ ) than during the rest of the experimental campaign (mean $-3.1 \mathrm{nmol} \mathrm{m}^{-2} \mathrm{~s}^{-1}$ ) (Fig. S3). Since the mixing ratio of $\mathrm{O}_{3}$ was quite variable during the campaign (Fig. 4), it is more interesting to look at the deposition velocity which underpins the surface exchange processes (Figs. $7 \mathrm{~b}$ and 8 ). The median $V_{\mathrm{dO}_{3}}$ during the organic fertilisation event exceeded the median over the rest of the experimental campaign by a factor of 2 . However, this increase in $\mathrm{O}_{3}$ deposition velocity cannot be explained by reaction with soil-emitted $\mathrm{NO}$ alone as the $\mathrm{O}_{3}$ flux is an order of magnitude larger than the NO flux.

Different pathways for the near-surface $\mathrm{O}_{3}$ removal are likely: (i) photolysis of $\mathrm{O}_{3}$ by ultraviolet light in the presence of water vapour forming $\mathrm{OH}$ radicals, (ii) gas phase re- 


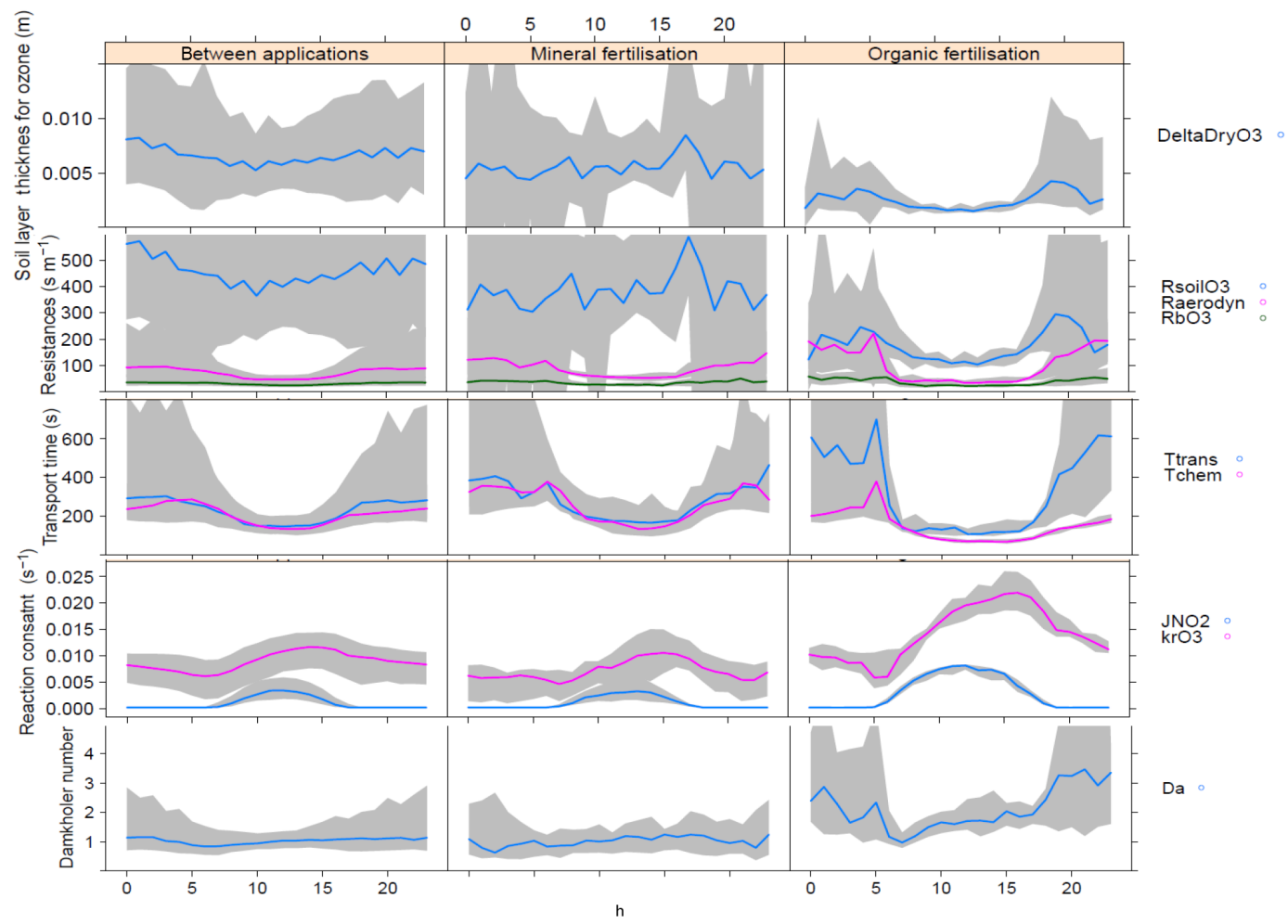

Figure 9. Diurnal cycles of the $\mathrm{O}_{3}$ penetration depth in the soil $\left(\Delta_{\mathrm{dryO}_{3}}\right)$, the aerodynamic $\left(R_{\mathrm{a}}\left(z_{\mathrm{ref}}\right)\right)$, boundary layer $\left(R_{\mathrm{bO}}\right)$ and soil resistances $\left(R_{\mathrm{soilO}_{3}}\right)$ for $\mathrm{O}_{3}$, the chemical reaction time $\tau_{\text {chem }}$ and transport time $\tau_{\text {trans }}$, the chemical reaction rates for $\mathrm{NO}_{2}$ photolysis $J_{\mathrm{NO}_{2}}$ and NO depletion by $\mathrm{O}_{3}\left(k_{\mathrm{r}} \times\left[\mathrm{O}_{3}\right]\right)$, and the Damköhler number $(\mathrm{Da})$, averaged over the periods of interest at the Grignon field site. The shaded areas represent the interquartile range.

actions with reactive VOCs and (iii) heterogeneous reactions with the soil or with molecules adsorbed on soil.

The NO mixing ratio was well correlated with the NO flux, with a normal correlation coefficient of $40 \%$ for the two weeks following the organic fertilisation (excluding 2425 August), while it was only $2 \%$ for the 7 -month period. This suggests that, following fertilisation, the ambient NO levels were mainly due to local emissions. The $\mathrm{NO}_{2}$ mixing ratio was less correlated with the $\mathrm{NO}_{2}$ flux, suggesting that $\mathrm{NO}_{2}$ levels were more related to advection from surrounding road traffic than from local emissions. Indeed, both NO and $\mathrm{NO}_{2}$ are emitted from road traffic and urban pollution, but the $\mathrm{NO}_{2}$ component quickly becomes prevalent as the plume is advected, especially in the presence of high $\mathrm{O}_{3}$ levels, as in our case (Carslaw, 2005; Minoura and Ito, 2010). The minimum night-time mixing ratio is mainly controlled by night-time wind velocity: the higher the night-time velocity, the higher the mixing ratio, due to a better mixing in the atmospheric surface layer. During conditions with lower wind speed, deposition and reaction with local $\mathrm{NO}_{x}$ sources lead to a high depletion of $\mathrm{O}_{3}$ during the night.

\subsection{To what extent are the chemical reactions between $\mathrm{NO}, \mathrm{NO}_{2}$ and $\mathrm{O}_{3}$ modifying the fluxes above the ground?}

Measured mixing ratios and fluxes of $\mathrm{NO}, \mathrm{NO}_{2}$ and $\mathrm{O}_{3}$ are affected by chemical reactions (Reactions SR1 to SR4 in the Supplement) in addition to emissions and deposition processes. Especially, the diurnal fluxes of $\mathrm{NO}_{2}$ observed from 18 to 23 August, were positive (emissions) and of the same order of magnitude as the NO fluxes, while they were negative afterwards. The simultaneous observation of positive $\mathrm{NO}$ and $\mathrm{NO}_{2}$ fluxes are typical for the NO-to- $\mathrm{NO}_{2}$ transformation below the flux observation level in the presence of high $\mathrm{O}_{3}$ mixing ratios. This phenomenon is called "apparent $\mathrm{NO}_{2}$ emissions" and was observed in other studies mainly above dense or tall canopies (Ammann et al., 2012; Min et al., 2014; Plake et al., 2015). For the Reactions (SR1)(SR2) to occur below the measurement height, the turbulent transport time $\left(\tau_{\text {trans }}\right)$ needs to exceed the chemical reaction time $\left(\tau_{\text {chem }}\right)$ (Arellano and Duynkerke, 1992; De Arellano et al., 1993; Lenschow and Delany, 1987; Plake et al., 2015; Stella et al., 2011a, 2012, 2013a). The Damköhler number $D a=\tau_{\text {trans }} / \tau_{\text {chem }}$ is often used to determine the conditions favourable for chemical reactions: in cases when $D a$ is higher 


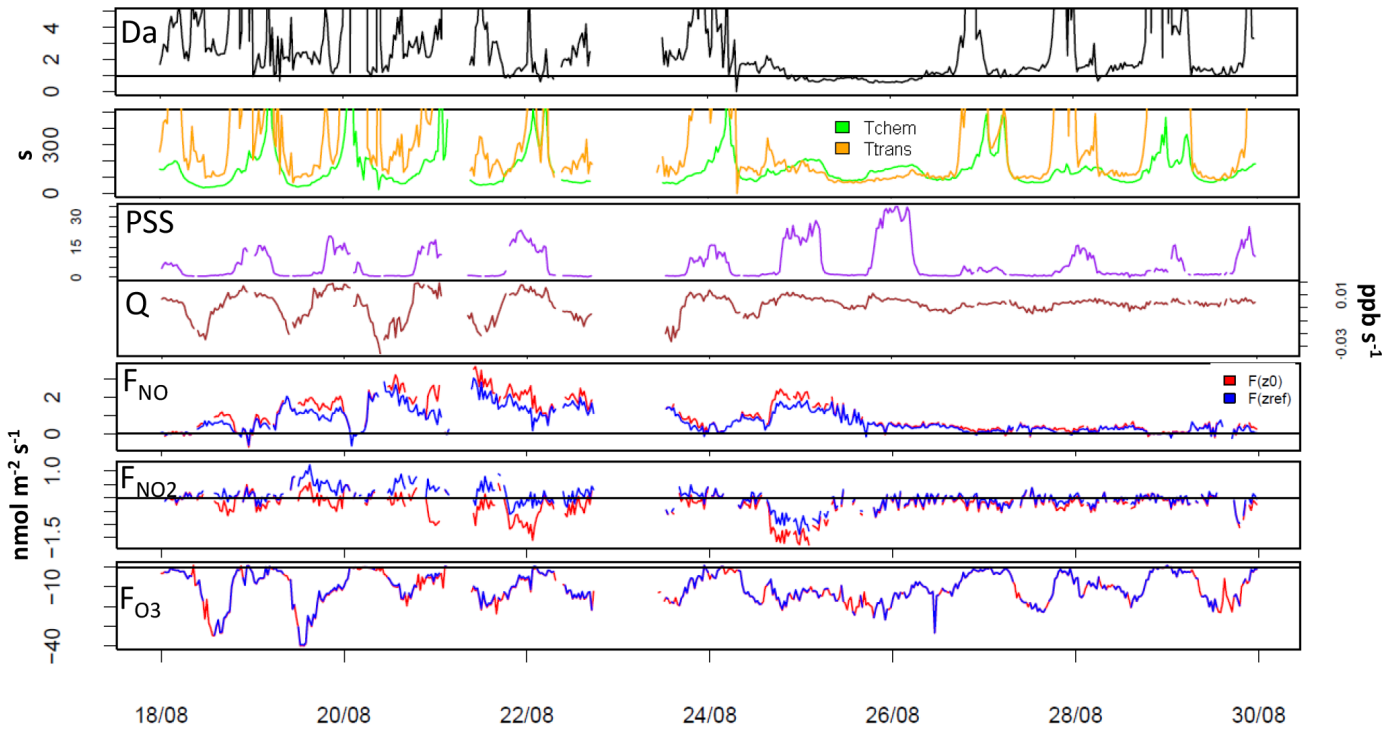

Figure 10. Half-hourly values of photo-stationary state ratio (PSS) and $Q=k_{\mathrm{r}}[\mathrm{NO}]\left[\mathrm{O}_{3}\right]-J_{\mathrm{NO}_{2}}\left[\mathrm{NO}_{2}\right]$ (s); chemistry and transport timescales $\left(\tau_{\text {chem }}\right.$ and $\left.\tau_{\text {trans }}\right)$ and Damköhler number $(D a)$; measured $\mathrm{NO}, \mathrm{NO}_{2}$ and $\mathrm{O}_{3}$ fluxes and surface fluxes as computed by assuming a logarithmic flux divergence profile $\left(F_{\mathrm{NO}}, F_{\mathrm{NO}_{2}}\right.$ and $\left.F_{\mathrm{O}_{3}}\right)$ at the Grignon field site.

than unity chemical reactions are faster than the transport (flux divergence), whereas $D a$ values smaller than 0.1 indicate that the influence of chemical reactions was negligible. The aerodynamic resistance $R_{\mathrm{a}}\left(z_{\mathrm{ref}}\right)$ (Eq. S8) was overall quite small and ranging from 45 to $128 \mathrm{~s} \mathrm{~m}^{-1}$ (first and third quantiles), hence leading to a quite short transport timescale (but larger than $100 \mathrm{~s}$ most of the time). The boundary layer resistance was around 22 and $43 \mathrm{~s} \mathrm{~m}^{-1}$ (first and third quantiles) for $\mathrm{O}_{3}$ (Fig. 9). The surface resistance for $\mathrm{O}_{3}$ was estimated as $R_{\mathrm{soilO}_{3}}=V_{\mathrm{dO}_{3}}^{-1}-R_{\mathrm{a}}\left(z_{\mathrm{ref}}\right)-R_{\mathrm{bO}_{3}}$, and dominated the other resistances ( 100 to $480 \mathrm{~s} \mathrm{~m}^{-1}$ ). The $\mathrm{O}_{3}$ penetration depth in the soil was estimated as the depth necessary to explain the measured $R_{\mathrm{SoilO}_{3}}$ if molecular diffusion in the soil pores is the main limitation factor. In practice this corresponded to the dry soil layer used in Personne et al. (2009). This depth ranged from 2 to $10 \mathrm{~mm}$ on average and was smaller at noon than during the night (Fig. 9). Overall, the chemical time $\tau_{\text {chem }}$ and the transport time $\tau_{\text {trans }}$ were of the same order of magnitude at any time of the day between applications and during mineral fertilisation, and $\tau_{\text {chem }}$ was smaller than $\tau_{\text {trans }}$ during the organic fertilisation. As a consequence, the Damköhler number was around unity most of the time and larger than unity during the organic fertilisation period, showing that the reaction between $\mathrm{O}_{3}, \mathrm{NO}$ and $\mathrm{NO}_{2}$ happened during transport from the ground to the $\mathrm{EC}$ measurement height at all times at this site. During the fertilisation event, the Damköhler number was especially high at night, when the transport time increased more substantially than the chemical timescale. These results are similar to findings by Stella et al. (2012) for the same site over bare soil. During the periods with vegetation, the increase of the trans- port timescale above the canopy was less than that of the chemical timescale during night-time, as the presence of vegetation increases the mixing, and, hence diminishes $R_{\mathrm{a}}\left(z_{\mathrm{ref}}\right)$.

The Damköhler number shows that $\mathrm{NO}$ reacts with $\mathrm{O}_{3}$ and that photolysis also plays a role. How does this affect the NO flux measured at the reference height compared to the one at the ground? We quantified this variation by numerically solving Eq. (S13), based on the model of Duyzer et al. (1995). Due to the reaction with $\mathrm{O}_{3}$, the calculated NO flux at the ground surface was on average $32 \%$ larger than that at the measurement height during the period 17-29 August (0.93 instead of $0.63 \mathrm{nmol} \mathrm{m}^{-2} \mathrm{~s}^{-1}$ ). This would represent an increase of $37 \mathrm{~g}$ of $\mathrm{N}$ emission following slurry spreading. For $\mathrm{NO}_{2}$, the calculated flux at the ground surface was mostly negative while it was mainly positive at the reference height during the period 18-22 August. On average the $\mathrm{NO}_{2}$ flux at the ground was $-0.33 \mathrm{nmol} \mathrm{m}^{-2} \mathrm{~s}^{-1}$ over the period 17 29 August while it was $-0.03 \mathrm{nmol} \mathrm{m}^{-2} \mathrm{~s}^{-1}$ at the reference height. For NO fluxes, the major discrepancy between fluxes at the surface and the measurement height occurs during periods with relatively large and stable values of the Damköhler number (Fig. 10), as this is the case when chemical reactions consume NO before it reaches the measurement height.

The derivation of surface fluxes with the Duyzer model also leads to a diurnal cycle of the NO flux that is closer to the one observed for ground temperature, corroborating the hypothesis that ground emissions are mostly due to nitrification for our site (Fig. 11).

Since the $\mathrm{O}_{3}$ deposition flux was much larger than the NO flux, the reaction with NO changed the absolute value by only $3 \%$ when comparing the flux at the measurement height 


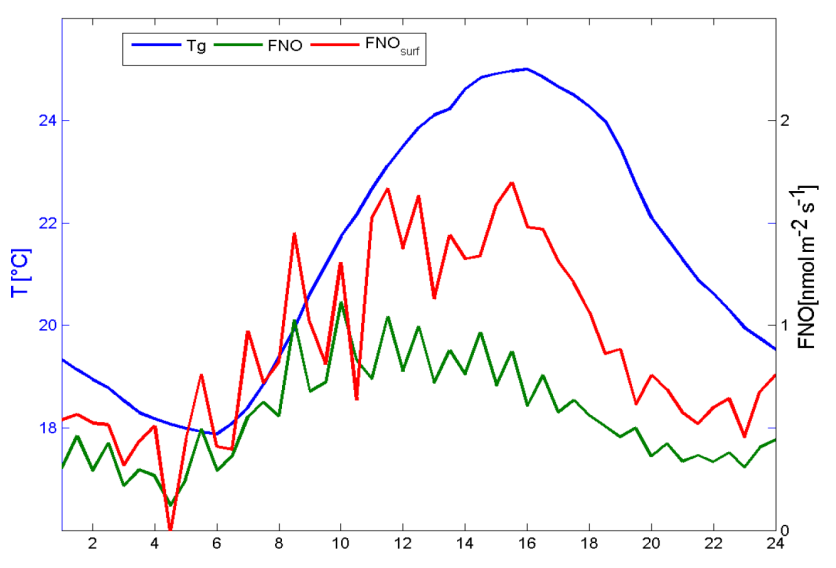

Figure 11. Diurnal cycles of ground temperature, NO flux at measurement height and at surface determined by the logarithmic profile in August 2012.

to the ground surface. Indeed, as only Reactions (SR1) and (SR2) are considered in Eqs. (S12) and (S13), which we used to numerically evaluate surface fluxes, we obtain: $\Delta\left[F_{\mathrm{NO}}\right]=$ $\Delta\left[F_{\mathrm{O}_{3}}\right]=-\Delta\left[F_{\mathrm{NO}_{2}}\right]=0.3 \mathrm{nmol} \mathrm{m} \mathrm{s}^{-2}$ where $\Delta$ stands for the difference between surface and measurement height.

\subsection{Why is $\mathrm{O}_{3}$ deposition increasing following organic fertilisation?}

We observed that following organic fertilisation (performed by injection and hence soil tillage), $\mathrm{O}_{3}$ deposition increased by a factor of 2 (as shown by the deposition velocity, Figs. 9 and 10). Several hypotheses may explain this increase: (1) the increased surface exchange due to soil tillage, (2) the reaction with $\mathrm{NO}$ emitted by the ground, and (3) the reaction with VOCs emitted by the ground.

The first hypothesis is that the increase in deposition velocity following the organic fertilisation could be due to a change in physical characteristics of the soil surface. Indeed, the application of cattle slurry with a trailing hose modifies the soil structure at the surface which consequently increases the available surface for $\mathrm{O}_{3}$ deposition, and therefore the deposition velocity. This hypothesis is consistent with the comparison of measured deposition velocities and modelled deposition velocities using the Stella et al. (2011a) $R_{\mathrm{SoilO}_{3}}$ parameterisation (see Sect. 3.3.3 and Fig. 6a). Indeed, while there is a good agreement between measured and modelled $V_{\mathrm{dO}_{3}}$ after the 26 August (i.e., after the rainfall event), modelled $V_{\mathrm{dO}_{3}}$ systematically underestimates measured $V_{\mathrm{d}}$ between slurry application and the rainfall event. Since the parameterisation of $R_{\mathrm{SoilO}_{3}}$ was obtained for the Grignon site over different periods, that means $R_{\mathrm{SoilO}_{3}}$ accounts for the mean soil structure of the Grignon site. Therefore, it can be hypothesised that (i) $R_{\text {soil }}$ is underestimated from slurry application to the rainfall event due to the change of soil surface structure, and (ii) after the rainfall event, the soil surface recovers its mean structure corresponding to the $R_{\mathrm{SoilO}_{3}}$ parameterisation.

The second hypothesis is that $\mathrm{O}_{3}$ would react with NO emitted by the soil. Although the reactions with NO during transport are shown to be small compared to the NO flux (Fig. 10), reactions in the soil surface layer may be more significant due to large NO concentrations in the soil, despite the fact that this layer is very small. A graph of the difference between the measured and the modelled ozone flux following fertilisation (Fig. S4) seems to show that the additional $\mathrm{O}_{3}$ deposition is correlated with the NO flux. This would mean that the $\mathrm{NO}_{2}$ produced in the soil by reaction with $\mathrm{NO}$ would be adsorbed on the soil surface either in the mineral phase or dissolved in the water phase as $\mathrm{NO}_{2}$. To evaluate this assumption further, we evaluated the Damköhler number in the soil surface layer by assuming that the layer depth is equal to the $\mathrm{O}_{3}$ penetration depth $\delta_{\mathrm{O}_{3} \text { soil }}$ (Fig. 9). In this layer the transport time is equal to soil resistance for $\mathrm{O}_{3}$ times the penetration depth $R_{\mathrm{SoilO}_{3}} \times \delta_{\mathrm{O}_{3} \text { soil }}$. We can evaluate the NO mixing ratio that would explain the additional $\mathrm{O}_{3}$ destruction at the surface, by searching for the value of $[\mathrm{NO}]_{\text {soil }}$ that satisfies $\tau_{\text {trans }}\left(\right.$ Soil, $\left.\mathrm{O}_{3}\right)=\tau_{\text {chem }}\left(\right.$ Soil, $\left.\mathrm{O}_{3}\right)$. By doing so, we found that $[\mathrm{NO}]_{\text {soil }}$ would need to reach 5 to $40 \mathrm{ppm}$ to explain the increase in $\mathrm{O}_{3}$ deposition following organic fertilisation. Gut et al. $(1998,1999)$ measured NO mixing ratios at a $2 \mathrm{~cm}$ depth in the soil under wheat with the membrane tube technique and report mixing ratios around $100 \mathrm{ppb}$ and always below $400 \mathrm{ppb}$ following fertilisation, which is $1-2$ orders of magnitude below the mixing ratio which would be needed to explain the observed $\mathrm{O}_{3}$ flux. Moreover, the rate of NO production in the soil surface layer would have to be equal to the $\mathrm{O}_{3}$ flux to the ground (around $20 \mathrm{nmol} \mathrm{m}^{-2} \mathrm{~s}^{-1}$ ) which is an order of magnitude larger than what Gut et al. (1998) or Laville et al. (2009) report as maximum NO flux. However, we should stress that both Gut et al. (1998) and Laville et al. (2009) report NO fluxes that were measured in the presence of $\mathrm{O}_{3}$ and hence would have been depleted by reaction with it in a similar way as here.

A third hypothesis is that $\mathrm{O}_{3}$ would react with VOCs emitted by the ground. Reactive VOCs such as sesquiterpenes and monoterpenes have been previously found to be emitted from soils (Horvath et al., 2012; Penuelas et al., 2014), and some of these sesquiterpene species react with $\mathrm{O}_{3}$ in the order of a few seconds. The reactions of $\mathrm{O}_{3}$ with larger terpenes are important sources of $\mathrm{OH}$, as well as the ozonolysis of simpler unsaturated compounds (Donahue et al., 2005). Currently, there are few or no data available on the emission of VOCs from slurry application. However, a recent study mainly focusing on quantification of odour emissions from soil application of manure slurry showed the formation of a certain number of VOCs, included organic sulfur compounds, carboxylic acids, alcohols, carbonyl compounds (ketones and aldehydes), aromatic compounds (phenols and indoles) and nitrogen compounds (Feilberg et al., 2015). Based on their analyses, the compound most responsible for the overall 
odour impact from the VOC emissions was 4-methylphenol. These authors also showed the emission of trimethylamine, a compound that can react quickly with $\mathrm{O}_{3}$, leading to formation of secondary organic aerosols (Murphy et al., 2007). Furthermore, these authors suggest that a large part of these VOCs are formed through ozonation reactions (i.e. byproducts of ozonation: methanol, acetone and acetaldehyde). Indeed, the slurry would be transported downwards through the soil, where efficient heterogeneous reactions can take place at particle interfaces. It has been shown that the heterogeneous reaction probabilities may be much greater than anticipated. For example, measurements on oxide surfaces with a chemical structure commonly found in VOCs (i.e. alkenes, terpenes, carbonyls) showed that the $\mathrm{O}_{3}$ reaction probability of a surface-attached alkene can be up to 5 orders of magnitude greater than for the same reaction in the gas phase (Stokes et al., 2008). In the same way, Fick et al. (2005) observed that ozonolysis reaction rates of some terpenes were much higher than predicted, possibly as a result of reactions on the surfaces used in their experiments. These results suggest that terpenes can remain on the surfaces, enhancing the $\mathrm{O}_{3}$ reactivity. Similarly, some other authors observed that surface reaction probabilities with $\mathrm{O}_{3}$ were 10 to 120 times greater than their corresponding gas-phase values (Dubowski et al., 2004; Springs et al., 2011). It is also known that soils can act as a sink of VOCs, by their adsorption to soil mineral particle surfaces and humic substances (Penuelas et al., 2014). Hence, it is likely that surface chemistry including photo-enhanced $\mathrm{O}_{3}$ uptake on organic matter (Jammoul et al., 2008; Reeser et al., 2009) may explain the increase in $\mathrm{O}_{3}$ deposition, a process not yet described in the literature. It may also be likely that $\mathrm{O}_{3}$ is destroyed by very reactive VOCs in the gas phase as hypothesised by Wolfe et al. (2011). These gas-phase reactions, however, require that the chemical reaction time be shorter than the turbulence transport time (Plake et al., 2015; Stella et al., 2012).

However, our study does not allow us to conclude definitively which of the three hypotheses is the most likely.

\section{Conclusions}

Eddy covariance flux measurements of the $\mathrm{NO}-\mathrm{NO}_{2}-\mathrm{O}_{3}$ triad during a 7-month period allowed evaluating several mechanisms controlling the exchange of these reactive trace gases with an agricultural soil. The eddy covariance technique proved to be suitable at capturing seasonal and diurnal dynamics of the fluxes, and allowed us to interpret flux behaviour according to meteorological variables, fertilisation practices and chemical reactions. Nevertheless, random uncertainty was particularly important $(>20 \%)$ during morning traffic peaks due to the non-stationarity of $\mathrm{NO}_{x}$ and $\mathrm{O}_{3}$ mixing ratios. As concerns $\mathrm{NO}_{2}$, uncertainty was even higher (up to $40 \%$ ) due to the indirect measurement method. We thus recommend caution in the use of the method in non- stationary conditions, and combined measurements of horizontal gradients of mixing ratios to quantify the effect of advection. Also, additional measurements of surface mixing ratios would be useful to check the reconstruction of surface fluxes that we performed by using the logarithmicprofile model of Duyzer. Finally, high $\mathrm{NO}_{2}$ to $\mathrm{NO}$ conversion efficiency should be assured to reduce uncertainty of $\mathrm{NO}_{2}$ fluxes.

In particular, the magnitude and temporal variability of NO emission fluxes following two fertilisation episodes were analysed, one in summer and the other one in winter. Mean NO emissions during the whole period were in agreement with previous studies on the same site. Emissions were significantly higher (Student $t$ test $p$ value lower than $2 \times 10^{-16}$, and a factor of 7 difference on the mean) during 2 weeks following organic fertilisation in August than during the rest of the experimental period. These large emissions are mainly due to favourable conditions for nitrification: soil water content around $20 \%$ and high temperatures. In February, following mineral fertilisation, the increase of NO emissions was less pronounced, although the same amount of $\mathrm{N}$ was applied. This difference is likely due to less favourable conditions for nitrification in February (low temperature and higher soil water content), rather than to the different form of fertiliser. On average over the whole period, we derived a loss of $0.26 \mathrm{~kg} \mathrm{Nha}^{-1}$ as NO from the field. With a total $\mathrm{N}$ input of $96 \mathrm{~kg} \mathrm{Nha}^{-1}$, this results in an $\mathrm{NO}$ emission factor of $0.27 \%$, which is in the lower range of earlier reported values on this site (Laville et al., 2011).

Our findings show that $\mathrm{NO}$ emissions from agricultural soils are limited $(0.27 \%$ of the N-NO applied over the 7-month period, which with a conservative estimation can be extended to a yearly amount). When hypothetically extended to France with an averaged nitrogen fertiliser use of $80 \mathrm{~kg} \mathrm{Nha}^{-1}$ over a fertilised area of around $26 \mathrm{Mha}$, this would lead to a total emission of $\mathrm{NO}_{x}$ of around $5.6 \mathrm{kt} \mathrm{N}-$ NO. This is negligible compared to national emissions which are around $240 \mathrm{kt} \mathrm{N}-\mathrm{NO}$ (CITEPA, 2015). The seasonality and spatial distribution of these emissions may, however, lead to air quality issues during spring and late summer-autumn which are the main fertiliser application periods in rural environments. Indeed, most of the emissions we measured occurred within a few weeks following fertilisation. In terms of ozone, our findings are in accordance with previous ones, showing that ozone is efficiently deposited throughout the year. This means that crops are participating through this process in the reduction of the atmospheric oxidising capacity.

The $\mathrm{O}_{3}$ deposition velocity was significantly higher following organic fertilisation than during the rest of the experiment (Student $t$ test $p$ value lower than $2 \times 10^{-16}$ and a factor 3 difference on the mean), despite the fact that vegetation was absent. This increase in $\mathrm{O}_{3}$ deposition could not be explained by the reaction of $\mathrm{O}_{3}$ with $\mathrm{NO}$ in the atmosphere as the NO flux was an order of magnitude smaller than that of $\mathrm{O}_{3}$. The process behind this ozone deposition in- 
crease remains to be discovered. We hypothesised three underlying processes: (1) increase in soil surface due to soil tillage, (2) reaction with $\mathrm{NO}$ in the soil layer and (3) reactions of $\mathrm{O}_{3}$ with VOCs emitted by the slurry. None of these hypotheses can be dismissed and further investigation is required. Experiments in controlled conditions are desirable to better understand these processes.

The evaluation of the chemical and turbulent transport times showed that reactions between $\mathrm{NO}, \mathrm{NO}_{2}$ and $\mathrm{O}_{3}$ below the measurement height occurred during the whole measurement period, leading to a depletion of NO and a build-up of $\mathrm{NO}_{2}$ from the ground to the measurement height. Following organic manure application, $\mathrm{NO}$ fluxes were reduced by $30 \%$ from the surface to measurement height, while the $\mathrm{NO}_{2}$ fluxes switched from deposition to uptake, being negative at the surface and positive at the measurement height. This phenomenon of "apparent $\mathrm{NO}_{2}$ emissions" was reported in other studies, especially above forests. Here it also appears to be important above a bare soil and at moderate measurement heights, during conditions of strong NO emissions and high ambient $\mathrm{O}_{3}$ mixing ratios.

Data availability. Data can be found in the Supplement.

\section{The Supplement related to this article is available online at doi:10.5194/bg-14-2225-2017-supplement.}

Competing interests. The authors declare that they have no conflict of interest.

Acknowledgements. This work was funded by the FP7 projects ECLAIRE (grant number 282910) and INGOS (grant agreement 284274), the French ANR project ANAEE, and ICOS France. The authors acknowledge the director of the AgroParsiTech Farm Dominique Tristan for allowing access to the field. We are grateful to the Max Planck Institute for Chemistry (Mainz, Germany) for the loan of a CLD 780TR analyser for the duration of the experiment. We also thank Gerardo Fratini for the precious support on issues concerning EddyPro, and Christof Ammann and Veronika Wolff for fruitful discussion about $\mathrm{NO}_{x}-\mathrm{O}_{3}$ chemical reactions. We also thank Polina Voylokov for her thorough correction of the paper and Anaïs Durand for helping on NO emission inventory evaluations.

Edited by: M. Williams

Reviewed by: N. Cowan and two anonymous referees

\section{References}

Ammann, C., Brunner, A., Spirig, C., and Neftel, A.: Technical note: Water vapour concentration and flux measurements with PTR-MS, Atmos. Chem. Phys., 6, 4643-4651, doi:10.5194/acp6-4643-2006, 2006.
Ammann, C., Wolff, V., Marx, O., Brümmer, C., and Neftel, A.: Measuring the biosphere-atmosphere exchange of total reactive nitrogen by eddy covariance, Biogeosciences, 9, 4247-4261, doi:10.5194/bg-9-4247-2012, 2012.

Andreae, M. O., Artaxo, P., Brandao, C., Carswell, F. E., Ciccioli, P., da Costa, A. L., Culf, A. D., Esteves, J. L., Gash, J. H. C., Grace, J., Kabat, P., Lelieveld, J., Malhi, Y., Manzi, A. O., Meixner, F. X., Nobre, A. D., Nobre, C., Ruivo, M. D. L. P., Silva-Dias, M. A., Stefani, P., Valentini, R., von Jouanne, J., and Waterloo, M. J.: Biogeochemical cycling of carbon, water, energy, trace gases, and aerosols in Amazonia: The LBA-EUSTACH experiments, J. Geophys. Res.-Atmos., 107, 8066, doi:10.1029/2001JD000524, 2002.

APIS: available at: http://www.apis.ac.uk/ indicative-critical-load-values (last access: 4 April 2017), 2016.

Arellano, J. and Duynkerke, P. G.: Influence of chemistry on the flux-gradient relationships for the $\mathrm{NO}-\mathrm{O}_{3}-\mathrm{NO}_{2}$ system, Bound.Lay. Meteorol., 61, 375-387, 1992.

Aubinet, M., Grelle, A., Ibrom, A., Rannik, U., Moncrieff, J., Foken, T., Kowalski, A. S., Martin, P. H., Berbigier, P., Bernhofer, C., Clement, R., Elbers, J., Granier, A., Grunwald, T., Morgenstern, K., Pilegaard, K., Rebmann, C., Snijders, W., Valentini, R., and Vesala, T.: Estimates of the annual net carbon and water exchange of forests: The EUROFLUX methodology, Adv. Ecol. Res., 30, 113-175, 2000.

Baldocchi, D. D.: Assessing the eddy covariance technique for evaluating carbon dioxide exchange rates of ecosystems: past, present and future, Glob. Change Biol., 9, 479-492, 2003.

Bollmann, A., Koschorreck, M., Meuser, K., and Conrad, R.: Comparison of two different methods to measure nitric oxide turnover in soils, Biol. Fert. Soils, 29, 104-110, 1999.

Breuninger, C., Oswald, R., Kesselmeier, J., and Meixner, F. X.: The dynamic chamber method: trace gas exchange fluxes $\left(\mathrm{NO}, \mathrm{NO}_{2}\right.$, $\mathrm{O}_{3}$ ) between plants and the atmosphere in the laboratory and in the field, Atmos. Meas. Tech., 5, 955-989, doi:10.5194/amt-5955-2012, 2012.

Brodeur, J. J., Warland, J. S., Staebler, R. M., and Wagner-Riddle, C.: Technical note: Laboratory evaluation of a tunable diode laser system for eddy covariance measurements of ammonia flux, Agr. Forest Meteorol., 149, 385-391, 2009.

Carslaw, D. C.: Evidence of an increasing $\mathrm{NO}_{2} / \mathrm{NO}_{x}$ emissions ratio from road traffic emissions, Atmos. Environ., 39, 4793-4802, 2005.

CITEPA: available at: https://www.citepa.org/fr/activites/ inventaires-des-emissions/secten (last access: 4 April 2017), 2015.

Corrsin, S.: Limitations of Gradient Transport Models in Random Walks and in Turbulence, in: Advances in Geophysics, edited by: Frenkiel, F. N. and Munn, R. E., Elsevier, 25-60, 1975.

Coyle, M., Nemitz, E., Storeton-West, R., Fowler, D., and Cape, J. N.: Measurements of ozone deposition to a potato canopy, Agr. Forest Meteorol., 149, 655-666, 2009.

Davidson, E. A.: Sources of Nitric-Oxide and Nitrous-Oxide Following Wetting of Dry Soil, Soil Sci. Soc. Am. J., 56, 95-102, 1992.

Davidson, E. A. and Kingerlee, W.: A global inventory of nitric oxide emissions from soils, Nutr. Cycl. Agroecosys., 48, 37-50, 1997. 
De Arellano, J. V.-G., Duynkerke, P. G., and Builtjes, P. J. H.: The divergence of the turbulent diffusion flux in the surface layer due to chemical reactions: the $\mathrm{NO}-\mathrm{O}_{3}-\mathrm{NO}_{2}$ system, Tellus $\mathrm{B}, 45,23-$ 33, 1993.

Donahue, N. M., Hartz, K. E. H., Chuong, B., Presto, A. A., Stanier, C. O., Rosenhorn, T., Robinson, A. L., and Pandis, S. N.: Critical factors determining the variation in SOA yields from terpene ozonolysis: A combined experimental and computational study, Faraday Discuss., 130, 295-309, 2005.

Dubowski, Y., Vieceli, J., Tobias, D. J., Gomez, A., Lin, A., Nizkorodov, S. A., McIntire, T. M., and Finlayson-Pitts, B. J.: Interaction of gas-phase ozone at $296 \mathrm{~K}$ with unsaturated self-assembled monolayers: A new look at an old system, J. Phys. Chem. A, 108, 10473-10485, 2004.

Dunfield, P. F. and Knowles, R.: Nitrogen monoxide production and consumption in an organic soil, Biol. Fert. Soil., 30, 153-159, 1999.

Duyzer, J. H., Deinum, G., and Baak, J.: The Interpretation of Measurements of Surface Exchange of Nitrogen-Oxides - Correction for Chemical-Reactions, Philos. T. R. Soc. A, 351, 231-248, 1995.

EEA: EMEP/EEA air pollutant emission inventory guidebook, Chapter 3D: Crop production and agricultural soils, EEA Technical Report No 21/2016, 2016.

Eugster, W. and Hesterberg, R.: Transfer resistances of $\mathrm{NO}_{2}$ determined from eddy correlation flux measurements over a litter meadow at a rural site on the Swiss plateau, Atmos. Environ., 30, 1247-1254, 1996.

Eugster, W. and Senn, W.: A Cospectral Correction Model for Measurement of Turbulent $\mathrm{NO}_{2}$ Flux, Bound.-Lay. Meteorol., 74, 321-340, 1995.

Fares, S., McKay, M., Holzinger, R., and Goldstein, A. H.: Ozone fluxes in a Pinus ponderosa ecosystem are dominated by nonstomatal processes: Evidence from long-term continuous measurements, Agr. Forest Meteorol., 150, 420-431, 2010.

Feilberg, A., Bildsoe, P., and Nyord, T.: Application of PTR-MS for Measuring Odorant Emissions from Soil Application of Manure Slurry, Sensors, 15, 1148-1167, 2015.

Ferrara, R. M., Loubet, B., Di Tommasi, P., Bertolini, T., Magliulo, V., Cellier, P., Eugster, W., and Rana, G.: Eddy covariance measurement of ammonia fluxes: Comparison of high frequency correction methodologies, Agr. Forest Meteorol., 158, 30-42, 2012.

Fick, J., Pommer, L., Astrand, A., Ostin, R., Nilsson, C., and Andersson, B.: Ozonolysis of monoterpenes in mechanical ventilation systems, Atmos. Environ., 39, 6315-6325, 2005.

Foken, T.: The energy balance closure problem: An overview, Ecol. Appl., 18, 1351-1367, 2008.

Geddes, J. A. and Murphy, J. G.: Observations of reactive nitrogen oxide fluxes by eddy covariance above two midlatitude North American mixed hardwood forests, Atmos. Chem. Phys., 14, 2939-2957, doi:10.5194/acp-14-2939-2014, 2014.

Gerosa, G., Marzuoli, R., Cieslik, S., and Ballarin-Denti, A.: Stomatal ozone fluxes over a barley field in Italy, "Effective exposure" as a possible link between exposure- and flux-based approaches, Atmos. Environ., 38, 2421-2432, 2004.

Gerosa, G., Vitale, M., Finco, A., Manes, F., Denti, A. B., and Cieslik, S.: Ozone uptake by an evergreen Mediterranean Forest (Quercus ilex) in Italy. Part I: Micrometeorological flux measure- ments and flux partitioning, Atmos. Environ., 39, 3255-3266, 2005.

Godde, M. and Conrad, R.: Influence of soil properties on the turnover of nitric oxide and nitrous oxide by nitrification and denitrification at constant temperature and moisture, Biol. Fert. Soils, 32, 120-128, 2000.

Gut, A., Blatter, A., Fahrni, M., Lehmann, B. E., Neftel, A., and Staffelbach, T.: A new membrane tube technique (METT) for continuous gas measurements in soils, Plant Soil, 198, 79-88, 1998.

Gut, A., Neftel, A., Staffelbach, T., Riedo, M., and Lehmann, B. E.: Nitric oxide flux from soil during the growing season of wheat by continuous measurements of the NO soil-atmosphere concentration gradient: A process study, Plant Soil, 216, 165-180, 1999.

Henault, C., Bizouard, F., Laville, P., Gabrielle, B., Nicoullaud, B., Germon, J. C., and Cellier, P.: Predicting in situ soil $\mathrm{N}_{2} \mathrm{O}$ emission using NOE algorithm and soil database, Glob. Change Biol., 11, 115-127, 2005.

Horii, C. V., Munger, J. W., Wofsy, S. C., Zahniser, M., Nelson, D., and McManus, J. B.: Fluxes of nitrogen oxides over a temperate deciduous forest, J. Geophys. Res.-Atmos., 109, D08305, doi:10.1029/2003JD004326, 2004.

Horvath, E., Hoffer, A., Sebok, F., Dobolyi, C., Szoboszlay, S., Kriszt, B., and Gelencser, A.: Experimental evidence for direct sesquiterpene emission from soils, J. Geophys. Res.-Atmos. 117, D15304, doi:10.1029/2012JD017781, 2012.

Huang, L., McDonald-Buller, E. C., McGaughey, G., Kimura, Y., and Allen, D. T.: The impact of drought on ozone dry deposition over eastern Texas, Atmos. Environ., 127, 176-186, doi:10.1016/j.atmosenv.2015.12.022, 2016.

IPCC (Houghton, J. T., Ding, Y., Griggs, D. J., Noguer, M., van der Linden, P. J., Dai, X., Maskell, K., and Johnson, C. A.): IPCC: Climate Change 2001: The Scientific Basis. Contribution of Working Group I to the Third Assessment Report of the Intergovernmental Panel on Climate Change 881 pp., 2001.

IPCC (Forster, P., Ramaswamy, V., Artaxo, P., Berntsen, T., Betts, R., Fahey, D. W., Haywood, J., Lean, J., Lowe, D. C., Myhre, G., Nganga, J., Prinn, R., Raga, G., M., S., and Van Dorland, R.): Changes in Atmospheric Constituents and in Radiative Forcing, in: Climate Change 2007: The Physical Science Basis. Contribution of Working Group I to the Fourth Assessment Report of the Intergovernmental Panel on Climate Change, edited by: Solomon, S., Qin, D., Manning, M., Chen, Z., Marquis, M., Averyt, K. B., Tignor, M., and Miller, H. L., Cambridge University Press, Cambridge, UK and New York, NY, USA, 2007.

Jammoul, A., Gligorovski, S., George, C., and D’Anna, B.: Photosensitized heterogeneous chemistry of ozone on organic films, J. Phys. Chem. A, 112, 1268-1276, 2008.

Kaimal, J. C. and Finnigan, J. J.: Atmospheric Boundary Layer Flows, Their structure and measurement, Oxford University Press, New York, 1994.

Kramm, G., Muller, H., Fowler, D., Hofken, K. D., Meixner, F. X., and Schaller, E.: A Modified Profile Method for Determining the Vertical Fluxes of $\mathrm{NO}, \mathrm{NO}_{2}$, Ozone, and $\mathrm{HNO}_{3}$ in the Atmospheric Surface-Layer, J. Atmos. Chem., 13, 265-288, 1991.

Lamaud, E., Loubet, B., Irvine, M., Stella, P., Personne, E., and Cellier, P.: Partitioning of ozone deposition over a developed maize crop between stomatal and non-stomatal uptakes, using eddycovariance flux measurements and modelling, Agr. Forest. Me- 
teorol., 149, 1385-1396, doi:10.1016/j.agrformet.2009.03.017, 2009.

Langford, B., Acton, W., Ammann, C., Valach, A., and Nemitz, E.: Eddy-covariance data with low signal-to-noise ratio: time-lag determination, uncertainties and limit of detection, Atmos. Meas. Tech., 8, 4197-4213, doi:10.5194/amt-8-4197-2015, 2015.

Laville, P., Henault, C., Gabrielle, B., and Serca, D.: Measurement and modelling of NO fluxes on maize and wheat crops during their growing seasons: effect of crop management, Nutr. Cycl. Agroecosys., 72, 159-171, 2005.

Laville, P., Flura, D., Gabrielle, B., Loubet, B., Fanucci, O., Rolland, M. N., and Cellier, P.: Characterisation of soil emissions of nitric oxide at field and laboratory scale using high resolution method, Atmos. Environ., 43, 2648-2658, 2009.

Laville, P., Lehuger, S., Loubet, B., Chaumartin, F., and Cellier, P.: Effect of management, climate and soil conditions on $\mathrm{N}_{2} \mathrm{O}$ and $\mathrm{NO}$ emissions from an arable crop rotation using high temporal resolution measurements, Agr. Forest Meteorol., 151, 228-240, 2011.

Lee, J. D., Helfter, C., Purvis, R. M., Beevers, S. D., Carslaw, D. C., Lewis, A. C., Moller, S. J., Tremper, A., Vaughan, A., and Nemitz, E. G.: Measurement of $\mathrm{NO}_{x}$ Fluxes from a Tall Tower in Central London, UK and Comparison with Emissions Inventories, Environ. Sci. Technol., 49, 1025-1034, 2015.

Lenschow, D. and Delany, A. C.: An analytic formulation for NO and $\mathrm{NO}_{2}$ flux profiles in the atmospheric surface layer, J. Atmos. Chem., 5, 301-309, 1987.

Lenschow, D. H. and Raupach, M. R.: The Attenuation of Fluctuations in Scalar Concentrations through Sampling Tubes, J. Geophys. Res.-Atmos., 96, 15259-15268, 1991.

Lenschow, D. H., Mann, J., and Kristensen, L.: How Long Is Long Enough When Measuring Fluxes and Other Turbulence Statistics, J. Atmos. Ocean. Technol., 11, 661-673, 1994.

Lenschow, D. H., Wulfmeyer, V., and Senff, C.: Measuring secondthrough fourth-order moments in noisy data, J. Atmos. Ocean. Technol., 17, 1330-1347, 2000.

Li, J. S., Chen, W., and Fischer, H.: Quantum Cascade Laser Spectrometry Techniques: A New Trend in Atmospheric Chemistry, Appl. Spectrosc. Rev., 48, 523-559, 2013.

Loubet, B., Genermont, S., Ferrara, R., Bedos, G., Decuq, G., Personne, E., Fanucci, O., Durand, B., Rana, G., and Cellier, P.: An inverse model to estimate ammonia emissions from fields, Eur. J. Soil Sci., 61, 793-805, 2010.

Loubet, B., Laville, P., Lehuger, S., Larmanou, E., Flechard, C., Mascher, N., Génermont, S., Roche, R., Ferrara, R. M., Stella, P., Personne, E., Durand, B., Decuq, C., Flura, D., Masson, S., Fanucci, O., Rampon, J.-N., Siemens, J., Kindler, R., Schrumpf, M., Gabriele, B., and Cellier, P.: Carbon, nitrogen and Greenhouse gases budgets over a four years crop rotation In northern France, Plant Soil, 343, 109-137, 2011.

Loubet, B., Cellier, P., Flechard, C., Zurfluh, O., Irvine, M., Lamaud, E., Stella, P., Roche, R., Durand, B., Flura, D., Masson, S., Laville, P., Garrigou, D., Personne, E., Chelle, M., and Castell, J.-F.: Investigating discrepancies in heat, $\mathrm{CO}_{2}$ fluxes and O-3 deposition velocity over maize as measured by the eddycovariance and the aerodynamic gradient methods, Agr. Forest Meteorol., 169, 35-50, 2013.

Mahrt, L.: Computing turbulent fluxes near the surface: Needed improvements, Agr. Forest Meteorol., 150, 501-509, 2010.
Marr, L. C., Moore, T. O., Klapmeyer, M. E., and Killar, M. B.: Comparison of $\mathrm{NO}_{x}$ Fluxes Measured by Eddy Covariance to Emission Inventories and Land Use, Environ. Sci. Technol., 47, 1800-1808, 2013.

Martin, R. V., Jacob, D. J., Chance, K., Kurosu, T. P., Palmer, P. I., and Evans, M. J.: Global inventory of nitrogen oxide emissions constrained by space-based observations of $\mathrm{NO}_{2}$ columns, J. Geophys. Res.-Atmos., 108, 4537, doi:10.1029/2003jd003453, 2003.

Massman, W. J. and Ibrom, A.: Attenuation of concentration fluctuations of water vapor and other trace gases in turbulent tube flow, Atmos. Chem. Phys., 8, 6245-6259, doi:10.5194/acp-86245-2008, 2008.

Mauder, M. and Foken, T.: Impact of post-field data processing on eddy covariance flux estimates and energy balance closure, Meteorol. Z., 15, 597-609, 2006.

Mauder, M., Foken, T., Clement, R., Elbers, J. A., Eugster, W., Grünwald, T., Heusinkveld, B., and Kolle, O.: Quality control of CarboEurope flux data - Part 2: Inter-comparison of eddy-covariance software, Biogeosciences, 5, 451-462, doi:10.5194/bg-5-451-2008, 2008.

Meixner, F. X.: The surface exchange of nitric oxide, Wiley Online Library, 1997.

Milford, C., Theobald, M. R., Nemitz, E., Hargreaves, K. J., Horvath, L., Raso, J., Dämmgen, U., Neftel, A., Jones, S. K., Hensen, A., Loubet, B., Cellier, P., and Sutton, M. A.: Ammonia fluxes in relation to cutting and fertilization of an intensively managed grassland derived from an inter-comparison of gradient measurements, Biogeosciences, 6, 819-834, doi:10.5194/bg-6-819-2009, 2009.

Min, K.-E., Pusede, S. E., Browne, E. C., LaFranchi, B. W., and Cohen, R. C.: Eddy covariance fluxes and vertical concentration gradient measurements of $\mathrm{NO}$ and $\mathrm{NO}_{2}$ over a ponderosa pine ecosystem: observational evidence for within-canopy chemical removal of $\mathrm{NO}_{x}$, Atmos. Chem. Phys., 14, 5495-5512, doi:10.5194/acp-14-5495-2014, 2014.

Minoura, $\mathrm{H}$. and Ito, A.: Observation of the primary $\mathrm{NO}_{2}$ and $\mathrm{NO}$ oxidation near the trunk road in Tokyo, Atmos. Environ., 44, 23 29,2010

Muller, J. B. A., Percival, C. J., Gallagher, M. W., Fowler, D., Coyle, M., and Nemitz, E.: Sources of uncertainty in eddy covariance ozone flux measurements made by dry chemiluminescence fast response analysers, Atmos. Meas. Tech., 3, 163-176, doi:10.5194/amt-3-163-2010, 2010.

Müller, M., Graus, M., Ruuskanen, T. M., Schnitzhofer, R., Bamberger, I., Kaser, L., Titzmann, T., Hörtnagl, L., Wohlfahrt, G., Karl, T., and Hansel, A.: First eddy covariance flux measurements by PTR-TOF, Atmos. Meas. Tech., 3, 387-395, doi:10.5194/amt-3-387-2010, 2010.

Murphy, J. G., Day, D. A., Cleary, P. A., Wooldridge, P. J., Millet, D. B., Goldstein, A. H., and Cohen, R. C.: The weekend effect within and downwind of Sacramento - Part 1: Observations of ozone, nitrogen oxides, and VOC reactivity, Atmos. Chem. Phys., 7, 5327-5339, doi:10.5194/acp-7-5327-2007, 2007.

Nieder, R. and Benbi, D. K.: Carbon and Nitrogen in the Terrestrial Environment, Springer, the Netherlands, 2008.

Oikawa, P. Y., Ge, C., Wang, J., Eberwein, J. R., Liang, L. L., Allsman, L. A., Grantz, D. A., and Jenerette, G. D.: Unusually high soil nitrogen oxide emissions influence air quality in 
a high-temperature agricultural region, Nat. Commun., 6, 8753, doi:10.1038/ncomms9753, 2015.

Oswald, R., Behrendt, T., Ermel, M., Wu, D., Su, H., Cheng, Y., Breuninger, C., Moravek, A., Mougin, E., Delon, C., Loubet, B., Pommerening-Röser, A., Sörgel, M., Pöschl, U., Hoffmann, T., Andreae, M. O., Meixner, F. X., and Trebs, I.: HONO Emissions from Soil Bacteria as a Major Source of Atmospheric Reactive Nitrogen, Science, 341, 1233-1235, 2013.

Pape, L., Ammann, C., Nyfeler-Brunner, A., Spirig, C., Hens, K., and Meixner, F. X.: An automated dynamic chamber system for surface exchange measurement of non-reactive and reactive trace gases of grassland ecosystems, Biogeosciences, 6, 405429, doi:10.5194/bg-6-405-2009, 2009.

Park, J.-H., Fares, S., Weber, R., and Goldstein, A. H.: Biogenic volatile organic compound emissions during BEARPEX 2009 measured by eddy covariance and flux-gradient similarity methods, Atmos. Chem. Phys., 14, 231-244, doi:10.5194/acp-14-2312014, 2014

Peltola, O., Hensen, A., Helfter, C., Belelli Marchesini, L., Bosveld, F. C., van den Bulk, W. C. M., Elbers, J. A., Haapanala, S., Holst, J., Laurila, T., Lindroth, A., Nemitz, E., Röckmann, T., Vermeulen, A. T., and Mammarella, I.: Evaluating the performance of commonly used gas analysers for methane eddy covariance flux measurements: the InGOS inter-comparison field experiment, Biogeosciences, 11, 3163-3186, doi:10.5194/bg-113163-2014, 2014.

Penuelas, J., Asensio, D., Tholl, D., Wenke, K., Rosenkranz, M., Piechulla, B., and Schnitzler, J. P.: Biogenic volatile emissions from the soil, Plant Cell Environ., 37, 1866-1891, 2014.

Personne, E., Loubet, B., Herrmann, B., Mattsson, M., Schjoerring, J. K., Nemitz, E., Sutton, M. A., and Cellier, P.: SURFATM-NH ${ }_{3}$ : a model combining the surface energy balance and bi-directional exchanges of ammonia applied at the field scale, Biogeosciences, 6, 1371-1388, doi:10.5194/bg-6-1371-2009, 2009.

Plake, D., Sörgel, M., Stella, P., Held, A., and Trebs, I.: Influence of meteorology and anthropogenic pollution on chemical flux divergence of the $\mathrm{NO}-\mathrm{NO}_{2}-\mathrm{O}_{3}$ triad above and within a natural grassland canopy, Biogeosciences, 12, 945-959, doi:10.5194/bg12-945-2015, 2015.

Prüss-Üstün, A., Wolf, J., Corvalaín, C., Bos, R., and Neira, M.: Preventing Disease through Healthy Environments: A Global Assessment of the Burden of Disease from Environmental Risks, World Health Organization, Geneva, Switzerland, 2016.

Reeser, D. I., Jammoul, A., Clifford, D., Brigante, M., D’Anna, B., George, C., and Donaldson, D. J.: Photoenhanced Reaction of Ozone with Chlorophyll at the Seawater Surface, J. Phys. Chem. C, 113, 2071-2077, 2009.

Remde, A., Slemr, F., and Conrad, R.: Microbial-Production and Uptake of Nitric-Oxide in Soil, Fems Microbiol. Ecol., 62, 221230, 1989.

Rummel, U., Ammann, C., Gut, A., Meixner, F. X., and Andreae, M. O.: Eddy covariance measurements of nitric oxide flux within an Amazonian rain forest, J. Geophys. Res.-Atmos., 107, 8050, doi:10.1029/2001JD000520, 2002.

Sintermann, J., Spirig, C., Jordan, A., Kuhn, U., Ammann, C., and Neftel, A.: Eddy covariance flux measurements of ammonia by high temperature chemical ionisation mass spectrometry, Atmos. Meas. Tech., 4, 599-616, doi:10.5194/amt-4-599-2011, 2011.
Skiba, U., Drewer, J., Tang, Y. S., van Dijk, N., Helfter, C., Nemitz, E., Famulari, D., Cape, J. N., Jones, S. K., Twigg, M., Pihlatie, M., Vesala, T., Larsen, K. S., Carter, M. S., Ambus, P., Ibrom, A., Beier, C., Hensen, A., Frumau, A., Erisman, J. W., Brueggemann, N., Gasche, R., Butterbach-Bahl, K., Neftel, A., Spirig, C., Horvath, L., Freibauer, A., Cellier, P., Laville, P., Loubet, B., Magliulo, E., Bertolini, T., Seufert, G., Andersson, M., Manca, G., Laurila, T., Aurela, M., Lohila, A., Zechmeister-Boltenstern, S., Kitzler, B., Schaufler, G., Siemens, J., Kindler, R., Flechard, C., and Sutton, M. A.: Biosphere-atmosphere exchange of reactive nitrogen and greenhouse gases at the NitroEurope core flux measurement sites: Measurement strategy and first data sets, Agr. Ecosyst. Environ., 133, 139-149, 2009.

Springs, M., Wells, J. R., and Morrison, G. C.: Reaction rates of ozone and terpenes adsorbed to model indoor surfaces, Indoor Air, 21, 319-327, 2011.

Stella, P., Loubet, B., Lamaud, E., Laville, P., and Cellier, P.: Ozone deposition onto bare soil: a new parameterisation, Agr. Forest Meteorol., 151, 669-681, 2011a.

Stella, P., Personne, E., Loubet, B., Lamaud, E., Ceschia, E., Béziat, P., Bonnefond, J. M., Irvine, M., Keravec, P., Mascher, N., and Cellier, P.: Predicting and partitioning ozone fluxes to maize crops from sowing to harvest: the Surfatm- $\mathrm{O}_{3}$ model, Biogeosciences, 8, 2869-2886, doi:10.5194/bg-8-2869-2011, $2011 \mathrm{~b}$.

Stella, P., Loubet, B., Laville, P., Lamaud, E., Cazaunau, M., Laufs, S., Bernard, F., Grosselin, B., Mascher, N., Kurtenbach, R., Mellouki, A., Kleffmann, J., and Cellier, P.: Comparison of methods for the determination of $\mathrm{NO}-\mathrm{O}_{3}-\mathrm{NO}_{2}$ fluxes and chemical interactions over a bare soil, Atmos. Meas. Tech., 5, 1241-1257, doi:10.5194/amt-5-1241-2012, 2012.

Stella, P., Kortner, M., Ammann, C., Foken, T., Meixner, F. X., and Trebs, I.: Measurements of nitrogen oxides and ozone fluxes by eddy covariance at a meadow: evidence for an internal leaf resistance to $\mathrm{NO}_{2}$, Biogeosciences, 10, 5997-6017, doi:10.5194/bg10-5997-2013, 2013a.

Stella, P., Personne, E., Lamaud, E., Loubet, B., Trebs, I., and Cellier, P.: Assessment of the total, stomatal, cuticular, and soil 2 year ozone budgets of an agricultural field with winter wheat and maize crops, J. Geophys. Res.-Biogeo., 118, 1120-1132, 2013 b.

Stokes, G. Y., Buchbinder, A. M., Gibbs-Davis, J. M., Scheidt, K. A., and Geiger, F. M.: Heterogeneous Ozone Oxidation Reactions of 1-Pentene, Cyclopentene, Cyclohexene, and a Menthenol Derivative Studied by Sum Frequency Generation, J. Phys. Chem. A, 112, 11688-11698, 2008.

Toenges-Schuller, N., Stein, O., Rohrer, F., Wahner, A., Richter, A., Burrows, J. P., Beirle, S., Wagner, T., Platt, U., and Elvidge, C. D.: Global distribution pattern of anthropogenic nitrogen oxide emissions: Correlation analysis of satellite measurements and model calculations, J. Geophys. Res.-Atmos., 111, D05312, doi:10.1029/2005JD006068, 2006.

Tuzet, A., Perrier, A., Loubet, B., and Cellier, P.: Modelling ozone deposition fluxes: The relative roles of deposition and detoxification processes, Agr. Forest Meteorol., 151, 480-492, 2011.

Williams, E. J. and Fehsenfeld, F. C.: Measurement of Soil-Nitrogen Oxide Emissions at 3 North-American Ecosystems, J. Geophys. Res.-Atmos., 96, 1033-1042, 1991.

Wolfe, G. M., Thornton, J. A., Yatavelli, R. L. N., McKay, M., Goldstein, A. H., LaFranchi, B., Min, K.-E., and Cohen, R. C.: Eddy covariance fluxes of acyl peroxy nitrates (PAN, PPN and MPAN) 
above a Ponderosa pine forest, Atmos. Chem. Phys., 9, 615-634, doi:10.5194/acp-9-615-2009, 2009.

Wolfe, G. M., Thornton, J. A., McKay, M., and Goldstein, A. H.: Forest-atmosphere exchange of ozone: sensitivity to very reactive biogenic VOC emissions and implications for incanopy photochemistry, Atmos. Chem. Phys., 11, 7875-7891, doi:10.5194/acp-11-7875-2011, 2011.
Yienger, J. J. and Levy, H.: Empirical-Model of Global SoilBiogenic $\mathrm{NO}_{x}$ Emissions, J. Geophys. Res.-Atmos., 100, 1144711464, 1995.

Zhu, Z. L., Sun, X. M., Zhao, F. H., and Meixner, F. X.: Ozone concentrations, flux and potential effect on yield during wheat growth in the Northwest-Shandong Plain of China, J. Environ. Sci.-China, 34, 1-9, 2015. 